\title{
MOVIMENTO E TEORIA FEMINISTA: É POSSÍVEL RECONSTRUIR ATEORIA FEMINISTA APARTIR DO SUL GLOBAL?
}

\author{
Marlise Matos
}

\begin{abstract}
RESUMO
Partindo da trajetória teórica de Nancy Fraser, o texto toma os recentes rumos da teorização feminista como emblemáticas da elaboração de um arcabouço teórico-analítico de fôlego na démarche das teorias da justiça e do feminismo contemporâneas, ancorado, porém, em considerações hegemonizadas do Norte global. Há, neste sentido, um "distanciamento" da teórica norte-americana em relação às agendas mais recentes do feminismo global (e em especial dos feminismos do Sul) e uma reflexão excessivamente baseada em um "olhar desde o ocidente". É a partir dessa constatação que recupero a crítica aos estudos de matriz anglosaxã, a partir da contribuição de C. T. Mohanty. Ao final, proponho a experiência de uma "quarta onda" dos movimentos e estudos feministas no Brasil e na América Latina, apontando para circuitos de difusão feminista operados a partir de distintas correntes horizontais de feminismos - negro, acadêmico, lésbico, masculino etc.
\end{abstract}

PALAVRAS-CHAVE: teoria e movimento feminista; justiça; participação política; transversalidade; interseccionalidade de gênero.

\section{INTRODUÇÃO}

Inicialmente como "estudo de mulheres" ou "estudos feministas", depois como "estudos de gênero" e, agora, mais recentemente, como estudos vinculados ao "campo feminista de gênero" (MATOS, 2008), os estudos protagonizados pela luta feminista das mulheres, desta vez no âmbito acadêmico, têm contribuído de modo substantivo para alterar a paisagem das teorias no campo social, cultural e político, seja aqui no Brasil ou no exterior. Este artigo se propõe debater a possibilidade de uma nova proposta teórica feminista e de uma nova onda para o feminismo em outra moldura (frame): do Sul para o Norte global.

Partindo de uma brevíssima apresentação da trajetória teórica de Nancy Fraser e, especialmente, de alguns comentários ao livro Reframing Justice (FRASER, 2005a) e de críticas a um artigo recente intitulado "Feminism, Capitalism and the Cunning of History" - publicado em abril de 2009 na New Left Review -, recupero o desenho de um arcabouço teórico no âmbito do feminismo norte-americano que tem produzido muito impacto nos estudos de gênero e feministas na América Latina e no Caribe. Tomo as construções de Fraser como emblemáticas da elaboração de um arcabouço teórico-analítico de fôlego na recente démarche das teorias da justiça e do feminismo, por sua vez profundamente ancorado em considerações hegemonizadas do Norte global (conduzido e organizado por meio de teorias anglosaxônicas ocidentais, que indiscutivelmente têm sido alçadas à categoria de "a boa" teoria). Entendo que a autora em questão direciona os esforços de sua obra no sentido de (re)construir um novo paradigma para as "teorias da justiça" no mundo capitalista contemporâneo. Contudo, tal esforço não seria justificável (e mesmo compreensível) se a mesma não tivesse as considerações sobre as dinâmicas do movimento feminista (do norte-americano, sobretudo) como um pano de fundo mobilizador de suas reflexões.

É neste sentido que se faz necessário acompanhar o percurso teórico feito pela autora em questão para entendermos uma das maiores limitações de suas construções recentes: seu olhar baseado nas discussões sobre a justiça social contemporânea e os esforços de (re)construção de modelos analíticos para o entendimento do capitalismo em moldes contemporâneos passarem paulatinamente a estar desvinculados de uma análise mais densa sobre as vicissitudes do feminis- 
mo global contemporâneo. Isto teria se dado, a meu ver, por certo "distanciamento" da teórica das agendas mais recentes do feminismo global (e, em especial, dos feminismos do Sul global) e por uma construção excessivamente baseada em um "olhar do ocidente" hegemônico.

Numa segunda parte do artigo acompanho também e reforço as considerações originais de crítica aos estudos de matriz feminista anglo-saxã (portanto, ocidental e do Norte global), a partir da contribuição de C. T. Mohanty (1984; 2003; 2006). Mohanty - uma teórica feminista do póscolonialismo - pode ser considerada uma das primeiras vozes contra-hegemônica no Norte global, que tenta dar destaque aos equívocos, malentendidos e problemas que uma visão teórica exclusivamente marcada "a partir de olhos ocidentais" traz para os debates dos feminismos e das questões centrais que afetam as mulheres no mundo.

Pinto (2003) relata a existência de três grandes momentos (ou ondas) do feminismo brasileiro: o primeiro teria se expressado na luta pelo voto no âmbito do movimento sufragista, numa luta pelo direito ao voto, luta, portanto, por direitos políticos - uma luta universal pela igualdade política. Tal fase foi organizada por mulheres das classes médias e altas e, freqüentemente, por filhas de políticos ou intelectuais da sociedade brasileira que tiveram a chance de estudar em outros países, tendo configurado, segundo Pinto, um "feminismo bem comportado e/ou difuso"1. O segundo momento do feminismo no Brasil teria nascido durante o clima político do regime militar no início dos anos 1970, o qual foi uma síntese tanto da desvalorização e da frustração de cidadania no país, quanto de um reforço na opressão patriarcal e teria se caracterizado por um movimento contrário de liberação, no qual as mulheres discutiam a sua sexualidade e as relações de poder, deslocando a atenção da igualdade para as leis e os costumes. As organizações de mulheres que se le-

\footnotetext{
1 A história das feministas brasileiras pode ser retraçada pelo menos até Nísia Floresta e sua livre tradução do texto clássico Direitos das mulheres e injustiça dos homens, de autoria de Mary Wollestonecraft, em 1832. Tendo sido ela a primeira brasileira a tentar desconstruir os estereótipos de gênero e a dominação das mulheres, em meados do século XIX.
}

vantaram em oposição ao militarismo formaram muitos grupos que consolidaram os interesses e demandas femininas, propiciando maior articulação delas na arena pública. Esta segunda onda caracterizou-se, no Brasil e nos demais países latino-americanos, então, como uma resistência contra a ditadura militar e, por outro lado, em uma luta contra a hegemonia masculina, a violência sexual e pelo direito ao exercício do prazer. Teríamos, então, a terceira fase, desta vez referida à forte participação das mulheres brasileiras em todo o processo de redemocratização e na construção daquilo que Pinto identifica como uma espécie de "feminismo difuso" e com maior ênfase ainda sobre processos de institucionalização e discussão das diferenças intragênero (ou seja: entre as próprias mulheres). Os movimentos sociais e também o feminista, defrontando-se com novas maneiras de conceber a cultura política e outras formas de se organizar coletivamente, desta vez passaram a se caracterizar por: 1) tentativas de reformas nas instituições consideradas democráticas (com a criação dos Conselhos da Condição Feminina, das Delegacias de Atendimento Especializado às Mulheres, por exemplo); 2) tentativas de reforma do Estado (com a forte participação das mulheres organizadas no processo da Assembléia Constituinte de 1988, por exemplo); 3) busca de uma reconfiguração do espaço público, por meio da forte participação de "novas" articulações dos movimentos de mulheres (mulheres negras, lésbicas, indígenas, rurais etc.); 4) uma posterior especialização e profissionalização do movimento. Este terceiro momento marca o início de uma aproximação cautelosamente construída junto ao Estado.

Após a construção do enquadramento geral das duas partes anteriores referentes à explicitação dos debates teóricos encabeçados por Fraser e Mohanty, proponho, finalizando este artigo, a experiência de uma nova "onda" para os movimentos feministas e também para os estudos e teorias feministas que, por sua vez, levem a sério a existência radical (ainda recente) de circuitos de difusão feminista operados a partir das mais distintas correntes horizontais de feminismos (acadêmico, negro, lésbico, masculino etc.), que se poderia chamar de "feminist sidestreaming" ou de "fluxo horizontal do feminismo" (HEILBORN \& ARRUDA, 1995; ALVAREZ, 2009). A "nova" onda toma a sério também a direção rumo a arenas pa- 
ralelas de atuação, seja no âmbito da sociedade civil ou no das fronteiras existentes entre esta e o Estado, e também é perceptível a partir da afirmação da importância de se considerar as fronteiras interseccionais, transversais e transdisciplinares entre gênero, raça, sexualidade, classe e geração. Tal difusão feminista, com certeza, tem produzido conseqüências políticas e culturais que oscilam desde as políticas estatais (com os sérios desafios propostos a partir da transversalidade e intersetorialidade), passando pelas exigências das ações de cooperação internacional, introjetandose na cultura popular até as reflexões mais íntimas e que tangenciam aspectos do reconhecimento da multidimensionalidade subjetiva e identitária. Por meio destes caminhos tem sido recorrente identificar trajetos pelos quais os feminismos parecem fluir horizontalmente. Eu destacaria ainda a existência concreta de esforços intencionais para estender o feminismo a outros movimentos sociais por meio de coligações, campanhas, seminários, capacitações e atividades afins.

A possibilidade de se pensar esta suposta "quarta" onda recente do feminismo no Brasil (e talvez na América Latina) ${ }^{2}$ pode ser demonstrada por meio: 1) da institucionalização das demandas das mulheres e do feminismo por intermédio da elaboração, implantação e tentativas de monitoramento e controle de políticas públicas para as mulheres que tenham claramente o recorte racial, sexual e etário, bem como a busca do poder político, inclusive o parlamentar; 2) da criação de novos mecanismos e órgãos executivos de coordenação e gestão de tais políticas no âmbito federal, estadual e municipal; 3) dos desdobramentos oriundos da institucionalização, com a criação de organizações não-governamentais (ONGs), fóruns e redes feministas e, em especial, sob a influência das inúmeras redes comunicativas do feminismo transnacional e da agenda internacional das mulheres; e, finalmente, e ainda mais importante, por meio de 4) um novo frame para a atuação do feminismo, desta vez numa perspectiva trans ou pós-nacional que deriva daí um

\footnotetext{
2 Não pretendo tomar o caso dos feminismos brasileiros como "paradigmático" na América Latina: reconheço a existência de diferenças e sentidos únicos aos diferentes feminismos na região. O efeito desejado é apenas da descrição de uma trajetória familiar, aquela que me tem feito pensar e propor este dinamismo da quarta "onda".
}

esforço sistemático de atuação em duas frentes concomitantes: uma luta por radicalização anticapitalista, por meio do esforço de construção da articulação entre feminismos horizontais, e de uma luta radicalizada pelo encontro de feminismos no âmbito das articulações globais de países na moldura Sul-Sul. É nesta parte final do artigo, tendo como pano de fundo tal conjunto de reflexões, que avanço a proposta ousada de se pensar na teoria feminista a partir de um novo frame do Sul global, bem como de se pensar uma "quarta onda" para o feminismo brasileiro e latino-americano. Vejamos a seguir.

\section{FRASER E SUA CONTRIBUIÇÃO PARA A CONSTRUÇÃO DA TEORIA POLÍTICA FE- MINISTA $^{3}$}

Para Luis Felipe Miguel (2005), a preocupação corrente de multiculturalistas e de distintos teóricos da diferença seria a de produzir, não uma teoria democrática, mas uma teoria da justiça. É justamente a este deslocamento que parte importante das teorias feministas dedica-se contemporaneamente: em parte isto se deve porque, desde a contribuição original de Rawls (1971), ficou patente para o mundo que as democracias ocidentais (e suas teorias subjacentes) vinham convivendo facilmente com um quadro desalentador de profundas desigualdades sociais e políticas. Dentre as contribuições diversificadas das teorias feministas contemporâneas sobre os debates estabelecidos acerca de temas cruciais como igualdade e diferença, teorias da justiça, Estado nacional, democracia e participação - destaca-se sobremaneira a contribuição de N. Fraser.

Fraser $(1995 ; 1999)$ ficou notabilizada internacionalmente por sua crítica contundente ao trabalho filosófico de Habermas ${ }^{4}$, especialmente ao seu conceito de esfera pública. Este último teve sua origem na obra Mudança estrutural da esfera

\footnotetext{
3 As traduções, ao longo deste artigo, de trechos de obras em idioma estrangeiro são de responsabilidade da autora.

4 A primeira crítica conhecida de Fraser (1995), na verdade, apontou para traços conservadores da teoria crítica de Habermas, que permaneceria androcêntrica e insensível às questões de gênero, já que, posicionando-se contra esta forma analítica que distingue e separa "sistema" e "mundo da vida", a crítica feminista afirmaria a necessidade da generificação, finalmente, da própria oposição entre público e privado. A autora quis ressaltar que, nestes espaços,
} 
pública (1984), em que Habermas tratou da gênese e transformação da "esfera pública burguesa". N. Fraser (1999) apontava, naquele momento, para o surgimento dos "subaltern publics", aqueles grupos sociais que, devido à concepção de uma esfera pública nacional e homogênea, estariam excluídos dos processos de deliberação pública, como as mulheres e as minorias étnicas. As principais críticas elaboradas por ela àquele momento podem ser assim resumidas: 1) os diferentes interlocutores na esfera pública não podem colocar em suspenso seus diferenciais de status e agir como se fossem iguais, trazendo implícita a consideração de que a igualdade social em modelos liberais e burgueses não é condição necessária à democracia; 2) existiriam múltiplas esferas públicas concorrentes e isto não representa necessariamente um afastamento da democracia, pelo contrário, a multiplicidade seria preferível à existência de uma única e compreensiva esfera públi$\mathrm{ca}^{5}$; 3) a esfera pública seria o local de deliberação acerca do bem comum e também acerca de todos os demais temas que fossem coletivamente

estariam marcados diferenciadamente os papéis entre os sexos, sendo central na sua argumentação que o próprio trabalho doméstico das mulheres, ao permanecer não-reconhecido e invisível, continuaria não sendo contado como uma efetiva contribuição para a reprodução dos sistemas estatal e econômico. A autora também se incumbe de indicar que a esfera pública burguesa habermasiana seria "artificial", "efeminada" e "aristocrática" e promoveria um "estilo mais austero de discurso e comportamento público: um estilo considerado como 'racional', 'virtuoso' e 'varonil'” (FRASER, 1999), tendo também cabido promover uma exclusão formal da mulher da vida pública e naturalizar, dicotomizando, espaços ideais para as mulheres, como a vida privada e doméstica e, em contrapartida, reificando a esfera pública como um espaço masculino.

5 Tanto em sociedades estratificadas como em sociedades multiculturais seria desejável a existência de esferas públicas múltiplas e concorrentes. Nas primeiras, diz a autora, a existência de arranjos que acomodem a contestação entre múltiplas esferas públicas concorrentes promove de forma mais adequada a paridade de participação do que em contextos em que há apenas uma única esfera pública e em que membros dos grupos subordinados não contam com arenas de deliberação e contestação. Fraser chama tais arenas de deliberação de "subaltern counterpublics", ou seja, "arenas discursivas paralelas em que membros dos grupos subordinados podem inventar e circular contra-discursos para formular interpretações de oposição referidas à sua identidade, interesses e necessidades" (FRASER, 1999) e afirma que a sua existência indica uma ampliação da contestação discursiva, fato que implica uma democratização do espaço público em sociedades estratificadas. alçados a tal condição e seria desejável, inclusive, a tematização de interesses e questões privadas (já que o "privado também é político") 6 . Por fim, Fraser afirma que o modelo de esfera pública desenvolvido por Habermas pressuporia uma separação rígida entre a sociedade civil e o Estado, o que nem sempre seria real ou mesmo desejável. Voltando-se à questão da igualdade, Fraser defendeu então que, apesar da inexistência de impedimentos formais à participação no debate público, alguns impedimentos informais ainda persistiriam.

Destaco o ecletismo teórico que pode ser percebido na trajetória teórica percorrida pela autora: ela insiste em levar em consideração, de modo simultâneo, tanto os fatores políticos quanto os sociais e econômicos, que, por sua vez, seriam observáveis nas diversas conjunturas globais. $\mathrm{Na}$ sequência de suas reflexões, Fraser passou a se digladiar, então, com a construção de uma nova teoria feminista da justiça social que incorporasse dimensões paradoxais não tratadas nem pelos liberais (mesmo as correntes do liberalismo igualitário) - que enfatizavam a justiça como equidade e destacavam a redistribuição econômica como o motor da promoção da igualdade e da justiça social -, nem pelos teóricos multiculturalistas ou comunitaristas, que, por sua vez, insistiam que a luta pelo reconhecimento deveria suplantar a luta por redistribuição. Para Fraser (2001), tornou-se desafiante o esforço de associar ambos os tipos de reivindicações em uma análise que incidiria em um "dualismo perspectivo", propondo uma concepção de justiça "bidimensional" associada ao monismo normativo da paridade na participação. Haveria assim duas formas correntes de compreensão da justiça: uma que foca a injustiça socioeconômica, enraizada na estrutura políticoeconômica da sociedade (manifestando-se por meio de distintas formas de exploração,

\footnotetext{
6 Não deveria haver uma definição apriorística do que deve ou não ser tido como fora dos limites do "público". Assim, diz a autora que "pelo contrário, a publicidade democrática requer garantias positivas de oportunidades para minorias convencerem os demais de que o que não era público no passado no sentido de ser uma questão relativa ao bem comum deve agora passar a sê-lo"(FRASER, 1999). Nesse sentido, a autora indica que a teoria social crítica deve olhar de modo atento para os termos "público" e "privado", percebendo-os não apenas como a designação de esferas sociais, mas como classificações culturais e rótulos retóricos que apresentam conseqüências prático-políticas importantes para a democracia.
} 
marginalização e privação material); e outra, cultural e simbólica, focando a injustiça advinda dos padrões sociais e culturais da representação, reconhecimento, interpretação e comunicação (estas seriam exemplificadas pelas manifestações do não-reconhecimento, da dominação cultural e do desrespeito).

Mais recentemente (FRASER, 2005a; 2005b; 2007a; 2007b; 2008), a autora passou a repensar a sua concepção e a incorporar uma terceira perspectiva especificamente política em seu paradigma bidimensional da justiça. Fraser passou a conside$\operatorname{rar}^{7}$, então, como uma terceira dimensão da justiça social, a representação política. Por meio do recurso teórico a uma suposta virada "pós-nacional" é que a autora passa a utilizar a nova categoria da representação, que vai lhe permitir problematizar as estruturas do governo e os processos de tomada de decisão: "pelas lentes das disputas por democratização, a justiça inclui uma dimensão política, enraizada na constituição política da sociedade e que a injustiça correlata é a representação distorcida ou a afonia política" (FRASER, 2005a, p. 128-129). O problema dos limites, segundo a autora, referese à necessidade de que uma teoria da justiça, para um mundo globalizado, deva se apresentar como tridimensional, incorporando a dimensão política da representação ao lado da dimensão econômica da distribuição e da dimensão cultural do reconhecimento.

A dimensão política da justiça referir-se-ia, então, à constituição da jurisdição do Estado e das regras de decisão pelas quais ele estrutura a contestação, sendo este o palco no qual as lutas por distribuição e reconhecimento seriam realizadas. Segundo Fraser: "Estabelecendo critérios de pertencimento social e determinando quem conta como membro, a dimensão política da justiça especifica o alcance das demais dimensões: diz quem está incluído e quem está excluído do conjunto daqueles intitulados a uma justa distribuição e re-

\footnotetext{
7 Foi a partir do diálogo e confronto com outra teórica política feminista de fôlego, Iris Young (2009), que surgiu a reflexão sobre a imposição arbitrária de apenas duas categorias focais para se conceber a justiça social. Segundo Young: “[...] essa categorização parece não deixar espaço para um terceiro aspecto, político, da realidade social, relativo às instituições e práticas do direito, da cidadania, da administração e da participação política" (idem, p. 199).
}

conhecimento recíproco. Estabelecendo as regras de decisão, a dimensão política estabelece os procedimentos para colocar e resolver as disputas em ambas as dimensões econômica e cultural: diz não somente quem pode fazer demandas por redistribuição e reconhecimento, mas também como tais demandas devem ser colocadas e adjudicadas" (idem, p. 44).

Para Fraser, agora preocupada com a questão da justiça numa perspectiva global e transnacional (ou pós-vestifaliana), algumas questões passariam a se colocar como centrais, quais sejam: qual seria a moldura adequada dentro da qual considerar as questões de justiça de primeira ordem? Quem seriam os sujeitos relevantes titulares de uma distribuição justa e de um reconhecimento recíproco em dado caso? E como deveríamos determinar "quem" seria finalmente relevante? Em um mundo globalizado, portanto, não somente o conteúdo da justiça, mas também a sua moldura estaria em disputa. Dizer que o político é uma dimensão conceitualmente específica da justiça seria também dizer que ele pode dar margem a espécies conceitualmente específicas de injustiças: ou seja, que haveria obstáculos especificamente políticos à paridade de participação, e estes, por sua vez, não seriam redutíveis à má-distribuição ou ao nãoreconhecimento, e surgiriam da constituição política da sociedade.

A dimensão política da justiça referir-se-ia, portanto, à representação - questão definidora do político para a autora -, sendo que para alcançar as esperadas operações da "política da representação" seria preciso alcançar três níveis: 1) contestar a falsa representação política comum; 2) contestar ao mau enquadramento; e 3) colocar como uma meta da justiça social a democratização do processo de estabelecimento do enquadramento (frame-setting). Portanto, o terceiro nível de injustiça referir-se-ia à questão relativa ao "como" deve-se operar na busca pela justiça social: a má representação meta-política, segundo a qual a ausência de arenas democráticas nega à maioria a chance de se engajar em termos de paridade nas tomadas de decisão sobre o "quem", impediria muitos esforços para se superar as injustiças.

Nesta fase das discussões, para Fraser, haveria então dois diferentes níveis de má-representação: 1) a falsa representação política comum: em que as regras de decisão negariam a alguns a 
chance de participar como pares (a questão central sendo a da representação intra-moldura e, mais especificamente, a dos sistemas eleitorais que negam injustamente a paridade participativa a um conjunto significativo de minorias ou daquelas regras ainda cegas em relação ao gênero que também funcionam de forma a negar paridade de participação política às mulheres; 2) o mau enquadramento (misframing): referir-se-ia ao aspecto do político de delimitação das fronteiras. A injustiça surgiria quando as fronteiras da comunidade são desenhadas de forma a excluir, de todo e por completo, algumas pessoas da chance de participar nas disputas autorizadas acerca da justiça. E esta seria, em última instância, o tipo de injustiça definidora da era globalizada. Trata-se, aqui, de um aspecto da gramática da justiça freqüentemente negligenciado. $O$ terceiro nível de injustiça refere-se, portanto, à questão do "como": diz das falhas na institucionalização da paridade de participação no nível meta-político. É a falsa representação metapolítica, segundo a qual a ausência de tais arenas democráticas correntemente negam à maioria a chance de se engajar em termos de paridade nas tomadas de decisão sobre o "quem", além de impedir também os esforços para se superar a injustiça (mesmo aquelas experimentadas em outras dimensões). A justiça como pari- dade de participação expressaria o caráter inerentemente reflexivo da justiça democrática no mundo contemporâneo, na medida em que esta seria uma noção de resultados que indicaria um princípio substantivo de justiça pelo qual se pode avaliar os arranjos sociais - "[...] só são justos se permitem a todos os atores relevantes participar como pares na vida social" (FRASER, 2005a, p. 59) - e seria ainda uma noção de processo, pois indicaria um padrão procedimental pelo qual se torna possível avaliar a legitimidade democrática das normas: “[...] são legítimas se podem garantir o assento de todos os envolvidos em um processo justo e aberto de deliberação, em que todos participam como pares" (ibidem).

Diante disso, com a mudança no enquadramento teórico, haveria uma nova proposta de modelos que acomodassem os processos políticos de tomada de decisão, principalmente por meio da deliberação democrática, levando à transformação da gramática própria no âmbito das teorias da justiça: em vez de teoria da justiça social, usar-se-ia a idéia de teoria da justiça democrática. Então, ao adotar uma abordagem democrática e crítica sobre a justiça, $o$ modelo teórico tridimensional - redistribuição, reconhecimento e representação - de Fraser conformar-se-ia em uma teoria da justiça democrática pósvestfaliana (Quadro 1).

QUADRO 1-A TEORIADA JUSTIÇADEMOCRÁTICA PÓS-VESTIFALIANADE NANCY FRASER

\begin{tabular}{|c|c|}
\hline $\begin{array}{l}\text { DIMENSÕES DO } \\
\text { PARADIGMA DA } \\
\text { JSTIÇA SOCIAL }\end{array}$ & "PROBLE MAS" DA JUSTIÇ Ai INJUSTIÇAS \\
\hline ECONÔMICA & $\begin{array}{l}\text { INUUSTIÇAS REFERIDAS À MÁ DISTRIBUIÇẪO } \\
\text { Ocorrem quando o ordenamento econômico da sociedade impede algumas } \\
\text { pessoas de desfrutarem a "plena participaçä́o" política. }\end{array}$ \\
\hline CULTURAL & $\begin{array}{l}\text { INJUSTIÇAS REFERIDAS AONẪO-RECONHECIMENTO } \\
\text { Ocorrem quando as pessoas também podem ser impedidas de interagir } \\
\text { politicamente como pares e em condiçốes de igualdade "por hierarquias } \\
\text { institucionalizadas de valor cultural que thes negam a legitimidade necessária". }\end{array}$ \\
\hline \multirow{4}{*}{ POLITICA } & INJUSTIÇAS REFERIDAS À FALSA REPRESENTAÇÃ̄O \\
\hline & $\begin{array}{c}\text { 1. Faisa representação poítica comum ocorrem quando as regras políticas } \\
\text { dentro de um determinado Estado nacional podem impedir'limitariconstranger a } \\
\text { participaçẫo de alguns; }\end{array}$ \\
\hline & $\begin{array}{c}\text { 2. Mau encuaçramento: ocorrem quando os limites de uma comunidade, } \\
\text { incorretamente, excluem algumas pessoasigrupos, removendo sua capacidade } \\
\text { de participaçấo; }\end{array}$ \\
\hline & $\begin{array}{c}\text { 3. Faisa representação metapoítica: ocorrem quando as elites, nacionais ou } \\
\text { transnacionais, "monopolizam a atividade de delimitaçẫo do enquadramento, } \\
\text { negando voz àqueles que podem ser prejudicados no processo, e bloqueando a } \\
\text { criaçẫo de instâncias democráticas, onde as últimas afirmaçốes podem ser } \\
\text { avaliadas e corrigidas". }\end{array}$ \\
\hline
\end{tabular}

FONTE: Held e Kaya apud Cypriano (2010). 
Dessa forma, vê-se que a tematização sobre a justiça social na obra de Fraser interpenetraria, cada vez mais, a discussão sobre democracia (e não se constituiria como excludente ou antagônica a esta) e, como será possível notar, também a dimensão política do Estado, que, também segundo Young (2000a), dar-se-ia sob o olhar da busca por maior inclusão política. Os dois elementos democracia e Estado - comparecem de modo bem específico nas elaborações recentes da autora.

Em 2007, Fraser (2007b) advogou a tese de que a segunda onda do feminismo norte-americano poderia ser dividida em três "fases": a dos anos 1960, marcados pela efervescência dos "novos" movimentos sociais (instalando-se uma ampliação do "imaginário feminista" por meio da exposição pública de aspectos da dominação masculina); a fase relativa à "política de identidades" (com a incorporação, a partir do arrefecimento tanto do vigor utópico da Nova Esquerda quanto dos insights anti-economicistas, de um "imaginário culturalista" que reinventa a política como reconhecimento); e a fase do feminismo transnacionalizado (que ocupou vários espaços de articulação política no contexto da globalização). É nesse mesmo texto que a autora "adverte" que a segunda fase teria sido especialmente desenvolvida pelos feminismos da América do Norte, e a terceira, pelos feminismos na Europa Ocidental.

Em artigo mais recente - "Feminism, Capitalism and the Cunning of History" (2009) - novas problematizações surgem, desta vez, relativas à dinâmica que envolve e articula de modo muito específico o movimento feminista norte-americano. Após a profícua abordagem sobre a justiça social na contemporaneidade que, inclusive, construiu de modo tão positivo o percurso até aqui apresentado, Fraser retoma, desta vez de modo, em meu entender, extremamente empobrecedor, uma perspectiva sobre os movimentos feministas (basicamente ancorada na experiência norte-americana) para articular suas relações com o capitalismo tardio da contemporaneidade. $\mathrm{O}$ distanciamento crítico da autora parece-me patente pelas escolhas feitas e que já estavam, em parte, "anunciadas" no texto de 2001 (FRASER, 2007b).

Ponto crítico e limitante no artigo é a espécie de reducionismo, a partir do Norte global, ao qual Fraser submeteu a discussão dos feminismos no mundo, associando-os a parâmetros e experiências exclusivas aos do movimento norte-americano que, como é sobejamente conhecido, opera por meio de um enquadramento exclusivamente liberal e capitalista já tão criticado, inclusive por Mohanty (2003). Parece demasiado limitador problematizar a dinâmica dos feminismos na contemporaneidade, partindo de sua necessária subjugação à chave capitalista liberal e a partir das referências ao Norte globalizado. Para a autora, ao menos neste texto, a agenda do movimento deslizaria do eixo histórico do capitalismo estatal (state-organized capitalism) para um capitalismo transnacional, pós-fordista e neoliberal (ver Quadro 2).

QUADRO 2-DINÂMICADA SEGUNDA ONDADO FEMINISMO NOS ESTADOS UNIDOS, SEGUNDO FRASER

\begin{tabular}{|c|c|c|}
\hline $\begin{array}{c}\text { FEMNISMO E O CAPITALISMO } \\
\text { ESTATAL }\end{array}$ & $\begin{array}{c}\text { FEMINISHO E O "NOVO } \\
\text { ESPÍRIT O DO CAPIT ALISHO" }\end{array}$ & $\begin{array}{l}\text { FEMINISHO E O PÓS- } \\
\text { NEOLIBERALISHO }\end{array}$ \\
\hline $\begin{array}{l}\text { Feminismo contra o } \\
\text { economicismo }\end{array}$ & $\begin{array}{l}\text { Feminismo anti-economicismo } \\
\text { ressignific ado }\end{array}$ & $\begin{array}{l}\text { Pós-neoliberal anti- } \\
\text { ec onomicismo }\end{array}$ \\
\hline $\begin{array}{c}\text { O feminismo buscou substituir } \\
\text { uma visẫo monista e } \\
\text { economicista da justiça por uma } \\
\text { visấo ampliada, tridimensional, } \\
\text { que compreendia economia, } \\
\text { cultura e política. }\end{array}$ & $\begin{array}{c}\text { As reivindicaçốes feministas por } \\
\text { justiça foram cadavez mais } \\
\text { elaboradas como reivindicaçốes } \\
\text { de reconhecimento da } \\
\text { identidade e da diferença. }\end{array}$ & $\begin{array}{c}\text { Adotar uma visão completa da } \\
\text { tridimensionalidade da justiça, } \\
\text { que possivelmente } \\
\text { contrabalance melhor as } \\
\text { dimensốes do reconhecimento, } \\
\text { da redistribuiçẫo e da } \\
\text { representaçẫo. }\end{array}$ \\
\hline $\begin{array}{l}\text { Feminismo contra o } \\
\text { androcentrismo }\end{array}$ & $\begin{array}{l}\text { Feminismo antiandrocentrismo } \\
\text { ressignific ado }\end{array}$ & $\begin{array}{l}\text { Pós-neoliberal anti- } \\
\text { androc entrismo }\end{array}$ \\
\hline $\begin{array}{c}\text { Luta para incorporar a justiç a de } \\
\text { gênero no capitalismo estatal, } \\
\text { como também incluir as questốes } \\
\text { sobre as mulheres na própria } \\
\text { esquerda radical. }\end{array}$ & $\begin{array}{c}\text { O capitalismo desorganizado } \\
\text { incorpora o discurso do avanço } \\
\text { das mulheres e da justiça de } \\
\text { gênero, ao mesmo tempo } \\
\text { incorporando um discurso sobre } \\
\text { a valorizaçẫo do trabalho } \\
\text { assalariado. }\end{array}$ & $\begin{array}{c}\text { O feminismo deve militar para } \\
\text { formas de vida que descentrem } \\
\text { o trabalho assalariadoe } \\
\text { valorizem atividades nẫo- } \\
\text { assalariadas, como o cuidado da } \\
\text { casa. }\end{array}$ \\
\hline
\end{tabular}




\begin{tabular}{|c|c|c|}
\hline $\begin{array}{c}\text { Feminismo contra o estatismo } \\
\text { Rejeiçẫo ao ethos burocrátic o- } \\
\text { administrativo do capitalismo } \\
\text { estatal. }\end{array}$ & $\begin{array}{c}\text { Feminismo anti-estatismo } \\
\text { ressignific ado } \\
\text { A perspectiva feminista que } \\
\text { procurava transformar o poder } \\
\text { estatal em meio para } \\
\text { empoderamento e justiça social } \\
\text { passa a ser utilizada como } \\
\text { discurso para legitimar a } \\
\text { mercantilizaça âo para a } \\
\text { limitaçẫo do Estado. }\end{array}$ & $\begin{array}{l}\text { Pós-neoliberal anti-estatismo } \\
\text { Busca por uma democracia } \\
\text { participativa, militando por uma } \\
\text { nova forma de organizaçẫo do } \\
\text { poder polític o, que subordine a } \\
\text { burocracia ao empoderamento } \\
\text { dos cidadẫos e cidadẫs. } \\
\text { Fortalecer o poder público. }\end{array}$ \\
\hline $\begin{array}{c}\text { Feminismo contra e } \\
\text { pró-vestfalianismo }\end{array}$ & $\begin{array}{c}\text { Feminismo contra e } \\
\text { Pró-vestalianismo ressignificado }\end{array}$ & $\begin{array}{l}\text { Pós-neoliberal } \\
\text { anti-vestfalianismo }\end{array}$ \\
\hline $\begin{array}{c}\text { Por um lado o movimento estava } \\
\text { sensivel às injustiças } \\
\text { transfronteiriças, principalmente } \\
\text { as feministas envolvidas como } 0 \\
\text { "mundo em desenvowimento". } \\
\text { Por outro lado, a maioria das } \\
\text { feministas viram no seu } \\
\text { respectivo Estado o lugar de } \\
\text { demandas para seus interesses } \\
\text { próprios. }\end{array}$ & $\begin{array}{c}\text { A globalicaçẫo permitiu novas } \\
\text { formas de ativismo feminista } \\
\text { (transnacional, multiescalar), } \\
\text { porém, com algumas } \\
\text { dificuldades, já que o que era } \\
\text { uma tentativa para ampliar o } \\
\text { alc ance da justiça além do } \\
\text { Estado-naçẫo acabou por se } \\
\text { integrar em alguns aspectos } \\
\text { com as nec essidades } \\
\text { administrativas de uma nova } \\
\text { forma de capitalismo. }\end{array}$ & $\begin{array}{c}\text { Militância por uma nova ordem } \\
\text { política pós-vestiphaliana que } \\
\text { seja multiescalar e democrática } \\
\text { a cada nível que seja capaz de } \\
\text { indicar. }\end{array}$ \\
\hline
\end{tabular}

FONTE: A autora, a partir de Fraser (2009) e Cypriano (2010).

A partir de tais considerações, pode-se afirmar que o enquadramento proposto não seria traduzível para as experiências feministas na América Latina (especialmente o Brasil) ou, ainda, para outros países e regiões do Sul global, mesmo que a autora reconheça o papel que vem sendo desenvolvido, por exemplo, pelos Fóruns Sociais Mundiais neste contexto. Fraser opera o efeito de condensar todo o período da década de 1970 até os dias atuais em uma única onda (a segunda onda) feminista (ainda que a mesma "contenha" três fases), em que haveria então uma agenda e um discurso confluindo com as demandas por redistribuição, reconhecimento e representação no primeiro momento, e no segundo haveria a conformação de um backlash (uma onda reversa), em que a agenda (atual), a partir da fragmentação do discurso feminista, seria utilizada e resignificada pelo discurso neoliberal. O ponto a ser destacado aqui é que Fraser, ao se aproximar das discussões sobre os modelos de capitalismo, opera, em sua própria obra, um backlash: enviesa seu olhar para os limites estritos das vicissitudes do Estado e do capitalismo no escopo estadunidense hegemônico global.
Nestes termos, parece-me evidente que os feminismos latino-americanos não podem ser reduzidos a tal desenho e trajetória propostos. Conforme sabemos, e veremos na última sessão desse artigo, os feminismos latino-americanos têm suas próprias vicissitudes e idiossincrasias históricas e não foram (ou são) utilizados ou recrutados (não por inteiro) pelas estratégias de cunho neoliberal, pois, conforme é sabido, a força do Sul global surgiu exatamente a partir daí: da sua na negação, sua reação e oposição aos avanços do neoliberalismo. Parte do feminismo latino-americano pode, sim, ter sido "vítima" de tal efeito perverso, porém parte significativa não e é a ela que irei me reportar para demonstrar a contribuição no sentido, justamente, do desmascaramento do discurso generificado proposto pelo neoliberalismo, mostrando também aos feminismos do Norte o rumo equivocado em que estes se encontram. Todavia, antes de estabelecermos os patamares teórico-conceituais desta crítica, remonto à contribuição indispensável de Chandra T. Mohanty, uma das pioneiras na ácida crítica à obliterada perspectivação teórico-feminista a partir do Norte global. 


\section{C.T. MOHANTY: UMA VOZ DISSONANTE DO SUL PARA O NORTE GLOBAL}

Mohanty (1984), em um artigo que já se tornou célebre 8 , "Under Western Eyes: Feminist Scholarship and Colonial Discourses", procurou identificar nos textos de feministas ocidentais aquilo que ela definiu como a "produção da "mulher do Terceiro Mundo' como um sujeito monolítico" (MOHANTY, 1984, p. 333), a partir da construção crítica de três princípios norteadores: 1) a afirmação de que "as mulheres" constituem-se em um grupo coeso e homogêneo, com interesses e desejos idênticos; 2) o uso acrítico de metodologias particulares de análise que procuram "provar" a existência desta universalidade e de sua correlata validade para os estudos de diferentes países (especialmente tendo-se como referência a permanência da dominação patriarcal e da opressão das mulheres como um fenômeno global); 3) esses dois aspectos anteriores, por gerarem a noção homogênea de opressão das mulheres como um único grupo, definiriam, por conseqüência, uma imagem ou representação específica das mulheres do Terceiro Mundo (aqui estaria ainda em jogo uma construção de relações de força em que a definição hegemônica de poder é reduzida a jogos binários de estruturas entre quem possui poder - homens - e aqueles que não o possuem - as mulheres, especialmente aquelas do Terceiro Mundo) $)^{9}$. Sua proposta, inicialmente vigorosa e original, teve repercussões imediatas no mundo acadêmico, já que, provocativamente, a obra localizava o feminismo acadêmico dentro do contexto global de dominação política e econômica do "Primeiro Mundo".

Com o artigo e a crítica, a autora procurou evidenciar modos de apropriação e de codificação de conhecimentos acadêmicos sobre as mulheres no Terceiro Mundo, forjados a partir de categorias analíticas desenvolvidas exclusivamente pelas

\footnotetext{
8 Mohanty chega mesmo a afirmar: “"Under Western Eyes' não foi apenas a minha primeira publicação no âmbito dos 'estudos feministas', permanece sendo o texto que marcou a minha presença na comunidade feminista internacional" (MOHANTY, 2003, p. 221).

9 Aqui a autora, de modo perspicaz, coloca-se a óbvia questão: "O que acontece quando a asserção 'as mulheres como um grupo oprimido' está situada no contexto dos escritos feministas que as teóricas ocidentais elaboram sobre as mulheres do terceiro mundo? É aqui que localizo o traço colonialista" (MOHANTY, 1984, p. 351).
}

teóricas anglo-saxãs e européias. No mesmo artigo, há a insistência da autora em reforçar a necessidade (já naquele momento) da formação ou construção de estratégias de coalizão entre as dimensões de classe, raça ou cor e nacionalidade na construção de tradições acadêmicas feministas contra-hegemônicas, que estariam em contraponto com as propostas (monolíticas) ocidentais. A autora, ao considerar as práticas tradicionalmente acadêmicas (o ler e o escrever, sejam críticos ou textuais) como inscritas em relações políticas, dá o devido destaque ao "como" as teorias feministas ocidentais estariam construindo uma representação distorcida, estável, anistórica e reducionista a respeito das mulheres e dos feminismos do Terceiro Mundo como: sexualmente limitadas, ignorantes, pobres, não-escolarizadas, tradicionais e conservadoras, voltadas essencialmente para o doméstico e a família, dependentes e vitimizadas pelo sistema sócio-econômico etc.

A denúncia de Mohanty situa-se, justamente, na necessidade de identificar nessas estratégias, que aparentemente seriam apenas de enunciação, como os feminismos ocidentais estariam se apropriando e efetivamente "colonizando" (portanto, oprimindo ou suprimindo), as complexidades fundamentais e os conflitos que seriam inerentes e que marcam a vida das mulheres de classes, raças, religiões, culturas e castas tão diferentes, em prol de uma visão binária e reducionista ${ }^{10}$, e alocando-as invariavelmente na categoria de "as outras". Já o convite que ela nos faz é o de se pensar como o feminismo acadêmico ocidental (assim como outros tipos de saberes) deveria(m) enfrentar o desafio de se situar e de examinar o papel efetivo que tem desempenhado no contexto econômico e político global. Nas palavras da autora: "Desde que as discussões dos vários temas que eu identifiquei anteriormente (por exemplo, o parentesco, educação, religião etc.) são conduzidos no contexto do relativo 'subdesenvolvimento' do Terceiro Mundo (que é nada menos do que injustificadamente o confuso desenvolvimento com um caminho separado tomado pelo ocidente em seu desenvolvimento, bem como ignorando a

\footnotetext{
10 Está claro que, na construção destas homogeneizações, as características de contraponto que identificam e qualificam as mulheres ocidentais, por oposição, seriam: mulheres escolarizadas, modernas, com controle sobre seus próprios corpos e sexualidade e liberdade e autonomia para tomar as próprias decisões.
} 
direcionalidade da relação de poder primeiro-terceiro mundo), as mulheres do terceiro mundo como um grupo ou categoria são automaticamente e necessariamente definidas como: religiosas (leia-se 'não progressista'), orientadas para a família (leiase 'tradicional'), menores legais (leia-se 'elas-sãoainda-não-conscientes-de-seus-direitos'), analfabetas (leia-se 'ignorantes'), domésticas (leia-se 'atrasadas') e, algumas vezes, revolucionárias ( ler 'o seu país-está-em-um-estado-de-guerra-onde-háque-lutar!'). Isso é como a 'diferença de terceiro mundo' é produzida” (MOHANTY, 1984, p. 352).

Portanto, finalizando o artigo, Mohanty defende o ponto de vista de que os estudos trans ou interculturais do e sobre o feminismo deveriam estar atentos, a um só tempo, tanto para as dimensões micropolíticas de contextualização, de subjetividades e de lutas específicas, quanto aos contextos macropolíticos dos sistemas políticos e econômicos globais: análises particulares, singulares do Terceiro Mundo deveriam ser ou estar ligadas a análises de escopo mais ampliado, aspirando, assim, à possibilidade da construção de estratégias de solidariedade feministas para além das fronteiras (aspecto este que, na revisão realizada em 2003, Mohanty insistiu em destacar ${ }^{11}$ ) Ocidente/Oriente, Leste/Oeste. Este artigo literalmente "caiu como uma bomba" nos estudos acadêmicos feministas norte-americanos, tendo recebido inúmeras críticas de todos os matizes (WALBY, 2000). A própria Mohanty admite que o artigo angariou grande notoriedade, pois ela foi (des)reconhecida por um conjunto variado de atribuições que oscilaram desde a atribuição da sua contribuição como sendo a de uma "filha desobediente" do feminismo branco até a de "mentora intelectual" das acadêmicas do Terceiro Mundo/imigrantes.

O fato é que a discussão vivaz e eloquente aqui rapidamente resumida passa a ser "justificada" 12 , então e posteriormente, pela própria autora em um

\footnotetext{
11 Nesse sentido cabe a citação literal do texto de 1984: "Coligações estratégicas que constroem identidades políticas em oposição para elas se basearem na generalização, mas a análise dessas identidades de grupo não podem ser baseadas em categorias universalistas e anistóricas" (MOHANTY, 1984, p. 349).

12 À página 225, a autora reconhece: "Basta dizer, no entanto, que não tenho arrependimentos e só profunda satisfação em ter escrito Under Western Eyes" (MOHANTY, 2003, p. 225).
}

segundo texto, "Under Western Eyes Revisted: Feminist Solidarity through Anticapitalist Strugle" (2003). Trata-se de um capítulo (o capítulo 19 de um livro intitulado, sintomaticamente, de Feminsim without Borders ${ }^{13}$ ) que retoma os debates e reconstrói os principais elementos a serem reconhecidos como ainda relevantes para a obra da autora, tomando como ponto de partida este momento inaugural, para colocá-lo em perspectiva. Neste segundo texto, Mohanty explicitamente reconhece, por um lado, a recente direcionalidade conservadora adotada nos últimos tempos pelos movimentos feministas norte-americanos, reconhecendo, inclusive, que parte da luta radical e anti-racista, teria passado a ocorrer fora do escopo destes movimentos; e, por outro, a virada "pósmoderna" e "pós-colonialista", tendo a sua contribuição sido alinhada no segundo tipo. A autora destaca, então, a intenção do texto original: "Eu não escrevi 'Under Western Eyes' como uma prova da impossibilidade do conhecimento transcultural igualitário e não colonizador, nem eu defino feminismo 'Ocidental' e do 'Terceiro Mundo' de tal forma oposicional em que não haveria a possibilidade de solidariedade entre o feminismo Ocidental e o do Terceiro Mundo. No entanto, isso foi como muitas vezes o ensaio foi lido e utilizado. Eu queria saber por que uma oposição tão acentuada se desenvolveu desta forma. Talvez o mapeamento intelectual e institucional em que eu escrevi na época e as mudanças que têm afetado a sua leitura, desde então, esclareceriam as intenções e as reivindicações do ensaio" (MOHANTY, 2003, p. 224).

Mohanty justifica-se pela crítica ácida apresentada no primeiro texto enfatizando que ela estaria acompanhando críticas do humanismo eurocêntrico e dirigindo especialmente as suas considerações contra as "falsas afirmações masculinas e universalizantes" ("false universalizing and masculinist assumptions"). Ou seja, a intenção original teria sido a de afirmar a importância de dimensões locais e localizadas que estaria definindo a categoria do "universal", inclusive e também para a categoria do feminismo. Sua contribuição teria sido a de chamar a atenção para esta forma enviesada de universalização com vistas a

13 Tradução livre: O Feminismo sem Fronteiras. 
recuperar, contudo, a possibilidade da construção de uma solidariedade básica feminista transversaliza-dora de fronteiras e não-colonizadora ("a nonco-lonizing feminist solidarity across borders"), em que seriam as "diferenças compartilhadas" entre distintas perspectivas do feminismo do Terceiro e do Primeiro Mundo as responsáveis por solidificar tal base solidária. Ou seja: a autora teria a intenção, não tão bem delineada no primeiro ensaio, de dar relevância e valorização críticas das diferenças. Seu objetivo seria o de identificar, nas diferenças, as possíveis conexões e os traços de compartilhamento que tornassem possível a construção de coalizões e de solidariedade transversalizadoras.

Reconhecendo o conjunto de enormes transformações experimentadas pelos Estados Unidos, e também pelo mundo, ao longo do período de mais de 16 anos que separam os dois ensaios, Mohanty, esclarecedoramente, revela: “'Ocidental' e 'Terceiro Mundo' explicam muito menos que as categorias de 'Norte-Sul' ou 'Um Terço-Dois Terços"” (MOHANTY, 2003, p. 226) ${ }^{14}$. Aqui a autora não se detém, evidentemente, apenas nas categorias semânticas, mas nos diferenciados sentidos que as mesmas podem evidenciar. $\mathrm{O}$ que estaria, portanto, em disputa nas discussões políticas contemporâneas seria, com a presença deste jogo terminológico que só faz evidenciar a concreta inadequação das categorias, a necessidade da construção de outras que possam elucidar, por sua vez, a fluidez e o poder das forças globalizantes que situariam de modo diferenciado as comunidades de pessoas (como maiorias ou minorias sociais) de modo muito disparatado, e desta forma estariam invisibilizando categorizações que pudessem ter poder de agência, de transformação para os grupos diferenciados nesse contexto transnacionalizado. Mohanty, neste segundo texto, localiza-se pessoalmente como fazendo parte dos "Dois Terços" dentro do "Um Terço", usu-

\footnotetext{
14 Aqui as designações "Norte-Sul", como categorias políticas, e não geográficas, evidenciariam as nações e as comunidades afluentes e privilegiadas do mundo transnacionalizado por oposição àquelas que seriam econômica e politicamente marginalizadas. Já as categorias "Um Terço-Dois Terços” (ESTEVA \& PRAKASH, 1998) estariam referidas às maiorias e minorias sociais, tendo como ponto de partida as diferenciadas condições de qualidade de vida, seja dentro ou fora das fronteiras nacionais dos países.
}

fruindo os privilégios desta posição, mas incorporando a perspectiva e a visão de solidariedade com as comunidades em luta nos "Dois Terços".

Reconhecendo um movimento, inclusive norte-americano, de maturidade das lutas feministas transnacionais, a autora também aponta para algumas transformações de uma "virada à direita" no contexto (que acompanharia a hegemonia global capitalista, a privatização, o crescimento do ódio religioso, étnico e racial) que julga serem relevantes nas últimas duas décadas e que estariam desafiando as lutas feministas em todo o globo: 1) o declínio das condições de autogoverno em algumas nações pobres (acompanhada do concomitante crescimento em significância de algumas instituições e corporações capitalistas transnacionais como a Organização Internacional do Comércio e a União Européia); 2) as condições de hegemonia do neoliberalismo e a naturalização dos valores capitalistas, influenciando nas decisões mais banais da vida cotidiana das pessoas; 3) o crescimento dos fundamentalismos religiosos e de sua retórica machista e racista; e 5) as desiguais construções de "vias de informação" ("information highway") e a militarização e masculinização globais acompanhadas do forte crescimento nos complexos industriais prisionais nos Estados Unidos e em outros países, opondo comunidades de mulheres e de homens.

Para Mohanty, uma “saída” possível seria, justamente, o reforço de uma política feminista trans ou intercultural ("politics offeminist cross-cutlural scholarship") que se esforçasse por construir as conexões entre o feminismo acadêmico e as organizações políticas anticapitalistas. Este esforço precisaria continuar baseado na compreensão da existência de uma ligação visceral entre as dimensões micropolíticas da vida cotidiana com aquelas do contexto macropolitico e econômico globais, com vistas à construção coletiva de uma prática feminista transnacional e anticapitalista, constituída, justamente, a partir de organizações políticas anticapitalistas baseadas desta vez na solidariedade feminista. Ao feminismo acadêmico, por sua vez, caberia a construção de uma crítica feminista transnacional que estaria fundada na âncora analítica de se tentar compreender a vida das comunidades de mulheres mais marginalizadas pelo mundo, com vistas a se construir, a partir daí, o paradigma mais inclusivo possível sobre a justiça social. O ponto de partida epistemo- 
lógico de Mohanty é a sua crença na ligação (que ela julga ser causal) entre as condições de localização e de experiências marginais e a habilidade dos agentes humanos em explicar e analisar traços da sociedade capitalista (recuperando, evidentemente, a matriz metodológica do materialismo histórico): "a perspectiva particular dos pobres indígenas e das mulheres do Terceiro Mundo/Sul pode nos oferecer a visão mais inclusiva possível do poder sistêmico global" (MOHANTY, 2003, p. 232).

A proposta de Mohanty, portanto, é a da construção de um "feminismo sem fronteiras" que tenha como ponto de partida os corpos e as vidas das mulheres e meninas do Terceiro Mundo/Sul (o lócus privilegiado onde o capitalismo global costuma inscrever suas leis e seu roteiro), na construção "da conscientização como o outro radical da globalização" (Dirlik apud MOHANTY, 2003). Sua proposta é a da aproximação do feminismo acadêmico com estas realidades globais profundamente atravessadas pelo gênero, classe e raça, de modo à não repetição, dentro do Terceiro Mundo/Sul, das interpretações de sentido e das perspectivas ocidentais: a construção coletiva de um projeto feminista localizado e contextualizado em sua forma anticapitalista, antiimperialista, que valorize as formas cotidianas de resistência coletiva das mulheres ao redor do mundo. Daí, Mohanty se propõe a um deslocamento de foco: do "olhar ocidentalizado" (especialmente aquele sobre os efeitos colonizadores do feminismo ocidental acadêmico) para um olhar de dentro dos espaços hegemônicos do mundo do "Um Terço", que necessitariam da reconstrução de um projeto de descolonização.

Mohanty reconhece que, devido à especificidade contextual das mulheres de Terceiro Mundo-Sul, o fato delas já estarem envolvidas nas lutas antiimperialistas e anticapitalistas desde sempre, evidencia que elas já possuiriam a visão mais ampliada das lutas anticolonialistas e antiracistas no mundo contemporâneo. Ela sugere, então, a construção de estratégias para uma "pedagogia antiglobalização" baseada em alguns princípios, como a internacionalização-globalização dos curricula no âmbito dos estudos de gênero e de mulheres (nos Estados Unidos). Esta estratégia seria baseada em formas de teorização relacionais, simultaneamente históricas-globais e singulareslocais, de modo a determinar "como" e "o quê" se pode aprender quando cruzamos as fronteiras culturais e de experiências (tal procedimento envolveria: "estudos feministas comparativos", um "modelo de solidariedade feminista" na busca das diferenças que "uniriam" as mulheres) e propõe também esforços acadêmicos de compreensão das lutas antiracistas e antimachistas e dos ativismos antiglobalização. O foco nesta última estratégia resgata então o esforço de reteorização de aspectos generificados e racializados que construíram o Estado, o mercado e a própria sociedade civil focalizando as experiências imprevistas de resistência aos efeitos devastadores da reestruturação global sobre as mulheres e as raças ou etnias.

Em um artigo de 2006 - "US Empire and the Project of Women's Studies: Stories of citizenship, complicity and dissent" -, Mohanty mobiliza argumentos para uma retomada da mobilização feminista, agora contra os avanços da militarização norte-americana após as invasões do Afeganistão e do Iraque. Ela identifica no comportamento bélico um conjunto não banal de "hierarquias de gênero e raça e xenofobia nacionalista" que mobilizariam as "linguagens do império e do imperialismo para consolidar um regime militarizado tanto interna quanto externamente aos limites territoriais norte-americanos" (MOHANTY, 2006, p. 9). A crítica passa a ser endereçada ao fato dos estudos acadêmicos americanos suportarem conexões espúrias entre conhecimento científico, poder corporativo e lucro capitalista. A autora claramente denuncia a experiência de um backlash com o crescimento exacerbado do "conservadorismo, neoliberalismo e hipernacionalismo na academia" norte-americana, a partir da "demonização do multiculturalismo e do feminismo nos anos 80 pela Nova Direita, em nome do politicamente correto" (idem, p. 14). Preocupada em identificar uma relação possível de ser estabelecida entre os estudos feministas e as categorias de nação e cidadania, Mohanty sintetiza: "Se os Estudos de Mulheres nos anos 1970 chamavam a atenção para a cidadania euro-americana, os dos anos 1980 moveram-se na direção de uma compreensão mutiracial e sexualizada de cidadania e nos anos 1990 deram atenção às construções nacionalistas e heterossexistas de cidadania. Embora muitas vezes de maneira problemática, em 2006, o projeto de cidadania permanece contestado pelos Estudos Feministas, sobretudo se formos tentar nos ver, mais uma vez, como fazendo parte no e do mundo, a partir de uma perspectiva não-imperialista" (idem, p. 17). 
Mohanty vai insistir, então, na necessidade de se "teorizar o lugar de imigrantes, pobres, mulheres de cor na narrativa dos estudos feministas sobre a cidadania, desafiando a narrativa de resgate das feministas privilegiadas norte-americanas, onde quer que esta apareça, como um aspecto crucial da práxis feminista de solidariedade neste momento" (idem, p. 14). Sendo a favor de um "projeto descolonizado e emancipatório de cidadania" que estaria baseado na criação de culturas democráticas do dissenso em que prevaleçam "as lentes antiracistas, anticapitalistas e não heteronormativas" (idem, p. 18), a autora conclui o artigo afirmando que a análise desta forma contestada de cidadania poderia facilitar "as possibilidades das solidariedades transnacionais além das fronteiras nos espaços acadêmicos". Nas suas ultimas palavras: "Claramente, estas solidariedades fazem parte da praxis transnacional feminista - ainda que estas não estejam centralizadas nos contextos dos feminismos acadêmicos norte-americanos" (ibidem). Vejamos, então, com o que as experiências feministas brasileiras e latino-americanas poderiam contribuir nesta construção.

\section{A PROPOSTA DE UMA TEORIA POLÍTICA FEMINISTAA PARTIR DO SUL COM BASE NA “QUARTA ONDA" DO FEMINISMO BRASILEIRO}

Tomo por referência e ponto de partida aqui a constatação da presença do momento pósvestifaliano já descrito (FRASER, 2005a; 2005b; 2008; 2009) nas relações político-sociais, ou mesmo na investigação de processos transnacionais experimentados pela e por meio da globalização (MOHANTY, 2003; YOUNG, 2007). Já faz parte de um determinado consenso entre as distintas teorias feministas o reconhecimento de uma moldura transnacional de fôlego para os movimentos feministas ao redor do mundo. Parto também do pressuposto de urgência de uma perspectiva solidária feminista "sem fronteiras", conforme afirma Mohanty (2003; 2006), que, por sua vez, passe a valorizar diferentes escalas de intervenção: os sub-nacionalismo, os regionalismos e os localismos, só para citar algumas. Seja qual for a melhor forma de conceitualização para tais processos correntes, deve-se aqui focar uma proposta alternativa de desenho cartográfico e geométrico que é teórico e orientado privilegiadamente pelo viés feminista: a isto me dedicarei nesta seção final.
Assim, pensando a partir das especificidades da experiência latino-americana (sobre a qual, infelizmente, não há como proceder a um maior detalhamento, a exemplo do que farei para o Brasil) e, em específico, das experiências do feminismo brasileiro, seria importante recuperar o que a literatura já cunhou como "ondas" do feminismo. Até o presente momento, foram feitas, no Brasil e na América Latina, várias tentativas de reconstituição da história destes movimentos, de suas agendas e contribuições. Entre estes, cabe mencionar, para o Brasil: Saffioti (1976); Blay (1984); Simões (1985); Alvarez (1988; 1990; 2000); Schumaher e Vargas (1993); Teles (1993); Pinto (1994; 2003); Saffioti e Muñoz-Vargas (1994); Santos e Moraes (1995); Soares (1998); Farah (2004); Costa (2005) e Brabo (2006). Para a América Latina, lembraria: Alvarez (2000; 2009a; 2009b), Vargas Valente (2002), Alvarez et alii (2003), Gusmán (2001) e Ribeiro (2006).

Todas estas autoras têm apontado como um importante marco do feminismo os anos 1970, tendo-se em vista as enormes limitações políticas daquele momento, que foi o da transição de um regime autoritário militar para o regime democrático. As autoras são unânimes em ressaltar a capacidade demonstrada pelas mulheres brasileiras de organização e manifestação política com o intuito de promover mudanças.

Ao contrário de um movimento bem organizado, no Brasil não podemos caracterizar períodos tão distintamente claros de movimentação de mulheres como sendo exclusivamente "feministas". Porém é necessário destacar que as "vozes feministas" aqui sempre surgiram diante das muitas estruturas opressoras e conservadoras, mesmo precocemente, desde o século XVII e XVIII. Apesar da existência de forte cultura patriarcal e de uma sociedade predominantemente masculina, sobretudo em termos políticos, as vozes feministas brasileiras aparece(ra)m dos lugares menos esperados e em momentos ainda menos propícios. Essas "vozes" chamaram a atenção de outras mulheres e abriram o caminho para a entrada de algumas delas na arena pública e, portando, para as suas próprias demandas. Pinto (2003) sintetizou a existência dos três grandes momentos do feminismo brasileiro apresentados na introdução deste artigo: o primeiro expresso por meio da luta pelo voto no âmbito do movimento sufragista um "feminismo bem comportado" -; o segundo 
experimentado durante o clima político do regime militar no início dos anos $1970^{15}$; e a terceira fase - uma espécie de "feminismo difuso"16: este momento teria se caracterizado "por forte dissociação entre o pensamento feminista e o movimento" e a "profissionalização do movimento por meio do aparecimento de um grande número de ONGs voltadas para a questão das mulheres" (PINTO, 2003, p. 91). Entendo que há hodiernamente uma forte tendência dos feminismos brasileiros e latino-americanos para uma renovada retomada e aproximação entre pensamento e movimento feministas.

Vou acrescentar às análises já estabelecidas a possibilidade de percepção, então, de uma "quarta fase" (mais recente) do feminismo brasileiro e latino-americano que, por sua vez, poderia ser demonstrada por meio: 1) da institucionalização das demandas das mulheres e do feminismo, por intermédio da entrada (parcial) delas no âmbito do Poder Executivo e Legislativo destes países; 2) da criação de órgãos executivos de gestão de políticas públicas especialmente no âmbito federal (mas também, no Brasil, de amplitude estadual e municipal); 3) da consolidação no processo de institucionalização das ONGs e das redes feministas e, em especial, sob a influência e a capacidade de articulação e financiamento do feminismo transnacional e da agenda internacional de instituições globais e regionais (United Nations Development Fund for Women, United Nations Children's Fund, Organização Internacional do Trabalho, Programa das Nações Unidas para o Desenvolvimento, Comité de América Latina y el Caribe para la Defensa de los Derechos de la Mujer, Comissão Econômica para a América Latina e o

\footnotetext{
15 Esta é também uma das maiores características distintivas (e não banal) dos feminismos latino-americanos, em relação aos femininos de matriz européia ou anglo-saxã: o seu enraizamento nas lutas contra os estados militarizados e ditatoriais.

16 Segundo Schumaher (2005): "Em 1982, a sociedade brasileira vivia um momento importante na política, com a convocação de eleições diretas para governadores. O feminismo contava com aliados em alguns partidos políticos, e o movimento reinaugurou sua aproximação com o Estado. Um grupo de feministas paulistas propôs a criação de um órgão específico, responsável pela defesa da cidadania feminina e a implementação de políticas públicas para as mulheres na estrutura do Estado. Nasciam assim, em 1993, os dois primeiros conselhos estaduais do Brasil, em São Paulo e Minas Gerais” (idem, p. 2).
}

Caribe, entre outras) referidas aos direitos das mulheres; 4) uma nova moldura teórica (frame) para a atuação do feminismo: trans ou pós-nacional, em que são identificadas uma luta por radicalização anticapitalista e uma luta radicalizada pelo encontro de feminismos e outros movimentos sociais no âmbito das articulações globais de países na moldura Sul-Sul. Importa destacar que esta é uma proposta pessoal de acréscimo de nova onda à periodização já consensuada de três momentos dos feminismos no Brasil.

Também afirmo aqui e retomo a dinâmica dos momentos capitalistas, conforme enunciado por meio das "ondas" anteriormente descritas pelo olhar de Fraser. A relativa "inovação" e apropriação aqui, contudo, é de minha inteira responsabilidade. Nesta direção, a proposta identificaria a segunda onda relativa ao capitalismo estatal com a onda do período neoliberal referida pela autora e que trataria, então, do período da "onguização" (ALVAREZ, 2000) e do "feminismo difuso e bem comportado" relatado por Pinto. A postulação de uma "quarta" onda referir-se-ia, por sua vez, à sugestão acrescentada teoricamente por Nancy Fraser, quando ela menciona um período pós-neoliberal - um "futuro aberto", para Fraser. O quadro abaixo, retirado das considerações elaboradas pela autora, foi acrescido de elementos a partir do que ela considerou importante. Os acréscimos são, portanto, de minha inteira responsabilidade e serviriam para tornar menos "limitadas" as considerações feitas por Fraser. Tudo o que está em itálico foi efetivamente acrescentado por mim.

Destaco especialmente a necessidade do acréscimo de outra forma de classificação para a segunda onda dos feminismos latino-americanos e brasileiro (aquela referida às especificidades da experiência do Sul global na América Latina), que teria sido experimentada ao longo dos anos 1960 e 1970, na região, e que se referiu à luta duríssima contra o capitalismo estatista ditatorial militarizado da América Latina. A fase seguinte, correspondente aos anos 1980 e 1990, além da ênfase nas reformas promovidas pelo Estado neoliberal e sua agenda de constrangimentos, com os respectivos impactos promovidos no movimento feminista (que levaram "os movimentos a se especializarem", enquanto o pensamento feminista "generalizava-se" (PINTO, 2003, p. 91)), traz também a urgência das práticas e discursos transnacionalizados e em rede como uma forma de resistência e também como forma propositiva de novo modelo 
de desenvolvimento para a região - um modelo altermundialista ${ }^{17}$ (emblemático no lema maior do Fórum Social Mundial: "Um outro mundo é possível"). Entendo, pois, que a "quarta" onda a que me refiro inicia sua configuração a partir desta terceira fase, indo na direção de consolidação a partir dos anos 2000, reforçando o caráter anti ou pósneoliberal promovido pelos movimentos. Entendo que inaugura aqui um movimento de profunda re- organização do Estado que passa a se ocupar, na região, de modo mais efetivo, com perspectivas, desta vez multidimensio-nais, da justiça social (e não apenas no eixo da redistribuição econômica). A "quarta" onda traz também os desafios da horizontalização dos movimentos feministas e da construção coletiva do diálogo intercultural e intermovimentos. Volto a estes pontos mais adiante.

QUADRO 3 - DINÂMICA DAS “ONDAS” DO FEMINISMO (NO BRASIL E NA AMÉRICA LATINA) EM SUA ARTICULAÇÃO COM O FEMINISMO DOS ESTADOS UNIDOS

\begin{tabular}{|c|c|c|c|}
\hline $\begin{array}{l}\text { FEMINISHO E O } \\
\text { CAPIT ALISHO } \\
\text { ESTATAL }\end{array}$ & $\begin{array}{l}\text { ANOS 1960/1970 } \\
\text { FEMINISHO E O } \\
\text { CAPITALISHO } \\
\text { ESTATISTA } \\
\text { DITATORIAL } \\
\text { MLITARIZADO DA } \\
\text { AMÉRICA LATINA }\end{array}$ & $\begin{array}{c}\text { ANOS 198019/90 } \\
\text { FEMNISHO E O "NOVO } \\
\text { ESPIRITO DO } \\
\text { CAPITALISHO": } \\
\text { REDEMOCRATIZAÇ̃̃O E } \\
\text { CRISE FISCAL DO ESTADO- } \\
\text { NEOLIBERALISHO }\end{array}$ & $\begin{array}{l}\text { ANOS } 2000 \text { EM } \\
\text { DIANTE } \\
\text { FEMINISHO E O PÓS- } \\
\text { NEOLIBERALISHO }\end{array}$ \\
\hline $\begin{array}{l}\text { Feminismo contra } \\
\text { o economicismo } \\
\text { o feminismo } \\
\text { buscou substituir } \\
\text { uma visấo monista } \\
\text { e economicista da } \\
\text { justiça por uma } \\
\text { visâo ampliada, } \\
\text { tridimensional, que } \\
\text { compreendia } \\
\text { ec onomia, cultura } \\
\text { e política. }\end{array}$ & $\begin{array}{l}\text { Feminismo anti- } \\
\text { economic ismo } \\
\text { milkarizado } \\
\text { O feminismo } \\
\text { estabelece parâmetros } \\
\text { de resistência à } \\
\text { min̈tarizaçäo e aos } \\
\text { abusose } \\
\text { arbitrariedades } \\
\text { políticas mesmo no } \\
\text { âmbito do } \\
\text { "desenvolvimentismo" } \\
\text { autorkário miñtar. }\end{array}$ & $\begin{array}{c}\text { Feminismo anti-economicismo } \\
\text { ressignificado } \\
\text { As reivindicaçốes feministas } \\
\text { por justiça foram cadavez } \\
\text { mais elaboradas como } \\
\text { rewindicaçốes de } \\
\text { reconhecimento da identidade } \\
\text { e da diferença. } \\
\text { Transnacionalização de } \\
\text { discursos e práticas do } \\
\text { feminismo }\end{array}$ & $\begin{array}{l}\text { Pós-neoliberal anti } \\
\text { economicismo } \\
\text { Adotar uma visẫo } \\
\text { completa da } \\
\text { muitidimensionalidade } \\
\text { da justiça, que } \\
\text { possivelmente } \\
\text { contrabalance melhor } \\
\text { as dimensổes do } \\
\text { rec onhecimento, da } \\
\text { redistribuiçẫo e da } \\
\text { representaçẫo. } \\
\text { Enfase sobre as } \\
\text { dimensões poíticas da } \\
\text { justiça social. }\end{array}$ \\
\hline $\begin{array}{l}\text { Feminismo contra } \\
0 \text { androcentrismo } \\
\text { Luta para } \\
\text { incorporar a justiça } \\
\text { de gênero no } \\
\text { capitalismo estatal, } \\
\text { como também } \\
\text { incluir as questốes } \\
\text { sobre as mulheres } \\
\text { na própria } \\
\text { esquerda radical. }\end{array}$ & $\begin{array}{c}\text { Feminismo contra o } \\
\text { androcentrismo } \\
\text { exacerbado } \\
\text { Luta para incomorar a } \\
\text { justiça poítica no } \\
\text { capitalismo estatal e } \\
\text { contra o Estado } \\
\text { ditatorial mascuino e } \\
\text { mijtarizado. }\end{array}$ & $\begin{array}{c}\text { Feminismo anti- } \\
\text { androcentrismo ressignificado } \\
\text { o capitalismo desorganizado } \\
\text { incorpora o discurso do } \\
\text { avanço das mulheres e da } \\
\text { justiça de gênero, ao mesmo } \\
\text { tempo incorporando um } \\
\text { discurso sobre avalorizaçẫo } \\
\text { do trabalho assalariado. } \\
\text { "ONGuização" do movimento, } \\
\text { articulaça e formaçäo de } \\
\text { redes entre distintas } \\
\text { expressöes da poítica } \\
\text { feminista. }\end{array}$ & $\begin{array}{l}\text { Pós-neoliberal anti } \\
\text { androcentrismo } \\
\text { o feminismo deve } \\
\text { militar para formas de } \\
\text { vida que descentrem o } \\
\text { trabalho assalariado e } \\
\text { valorizem atwidades } \\
\text { nẫo-assalariadas, } \\
\text { como o cuidado da } \\
\text { casa; } \\
\text { e que valorizem as } \\
\text { formas femininas de } \\
\text { resistência ao } \\
\text { captalismo, ao } \\
\text { racismo eao } \\
\text { machismo }\end{array}$ \\
\hline
\end{tabular}

17 A Marcha Mundial de Mulheres (MMM) é uma das instituições recentes do feminismo transnacional que pleiteia a legitimidade organizacional de mulheres no sentido de se alinharem a uma agenda radical anti-capitalista e antipatriarcal, fazendo com que uma rede de seis mil grupos de 159 países e territórios façam parte deste movimento. A partir de tal caso, é possível estabelecer certos padrões do que hoje é conhecido como feminismo transnacional: um movimento atento às intersecções entre nacionalidade, raça, gênero, sexualidade e exploração econômica numa escala mundial, em decorrência principalmente do surgimento do capitalismo global; um movimento auto-intitulado altermundialista, por sua luta de cunho internacional contra o neoliberalismo e pela busca por maior justiça social. 


\begin{tabular}{|c|c|c|c|}
\hline $\begin{array}{c}\text { Feminismo contra } \\
\text { o estatismo }\end{array}$ & $\begin{array}{l}\text { Feminis mo contra o } \\
\text { estatismo autoritário }\end{array}$ & Feminismo anti-estatismo & $\begin{array}{l}\text { Pós-neoliberal de } \\
\text { reelaboraço estata! }\end{array}$ \\
\hline \multirow[t]{2}{*}{$\begin{array}{l}\text { Rejeiçẫo ao ethos } \\
\text { buroc rático- } \\
\text { administrativo do } \\
\text { capitalismo estatal. }\end{array}$} & $\begin{array}{c}\text { Rejejção compieta, } \\
\text { resistência e iuta } \\
\text { armada contra a } \\
\text { ditadura mintar. } \\
\\
\text { identidade feminista } \\
\text { mais estrekta } \\
\text { vinculada à resistência } \\
\text { à iuta armada e depois } \\
\text { à Anistia aos presos } \\
\text { políticas }\end{array}$ & 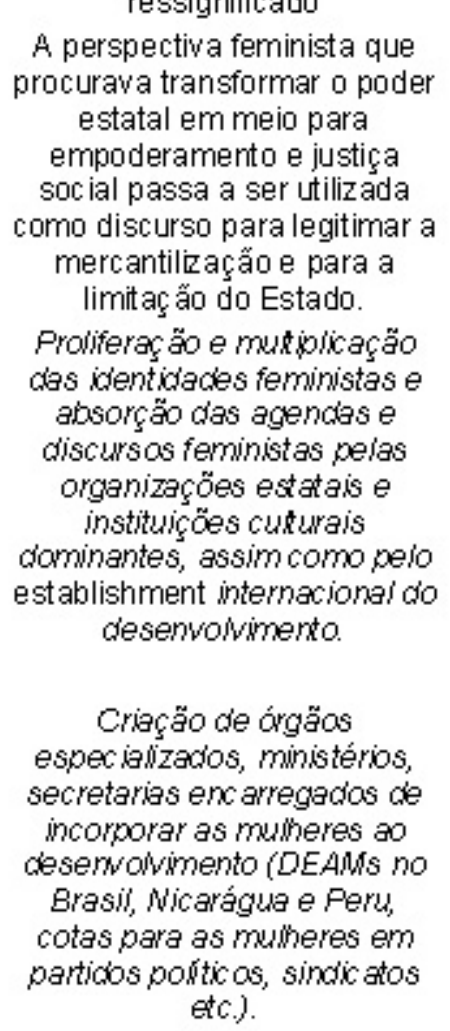 & $\begin{array}{c}\text { Busca por uma } \\
\text { democ racia } \\
\text { efetivamente } \\
\text { participativa, militando } \\
\text { por uma nova forma de } \\
\text { organizaçấo do poder } \\
\text { político, que subordine } \\
\text { a burocracia ao } \\
\text { empoderamento dos } \\
\text { cidadấos e cidadấs. } \\
\text { Fortalecer o interesse } \\
\text { púbico na construção } \\
\text { de espaç as } \\
\text { intermediários entre } \\
\text { Estado e sociedade } \\
\text { civi, para reelaboraçăo } \\
\text { das aços estatais } \\
\text { (Conferências, Planos, } \\
\text { poíticas púbicas } \\
\text { foc alizadas e } \\
\text { afirmativas etc.). }\end{array}$ \\
\hline & & $\begin{array}{l}\text { Organismas da ow } \\
\text { fortalecendo e consolidando } \\
\text { demandas feministas } \\
\text { nacionais e regionais por } \\
\text { maior justiça de genero. }\end{array}$ & \\
\hline $\begin{array}{c}\text { Feminismo contra } \\
\text { e pró- } \\
\text { vestfalianismo }\end{array}$ & $\begin{array}{l}\text { Feminismo contra e } \\
\text { pró-vestralianismo } \\
\text { Primeiras tentativas de }\end{array}$ & $\begin{array}{l}\text { Feminismo c ontra e } \\
\text { pró-vestfalianismo } \\
\text { ressignificado }\end{array}$ & $\begin{array}{l}\text { Pós-neoliberal } \\
\text { anti-vestfalianismo } \\
\text { Militância nor uma }\end{array}$ \\
\hline $\begin{array}{l}\text { Por um lado o } \\
\text { movimento estava } \\
\text { sensivel às } \\
\text { injustiças } \\
\text { transfronteiriças, } \\
\text { principalmente as } \\
\text { feministas }\end{array}$ & $\begin{array}{l}\text { articulação e diálogo } \\
\text { entre as feminismos } \\
\text { brasileiros e demais } \\
\text { feminismos latino- } \\
\text { americanos. }\end{array}$ & $\begin{array}{c}\text { A globalização permitiu novas } \\
\text { formas de ativismo feminista } \\
\text { (transnacional, multiescalar), } \\
\text { porém, com algumas } \\
\text { dific uldades, já que o que era } \\
\text { uma tentativa para ampliar o } \\
\text { alcance da justiça além do }\end{array}$ & $\begin{array}{l}\text { nova ordem política } \\
\text { pós-vestifaliana que } \\
\text { seja multiescalar e } \\
\text { democrática a cada } \\
\text { nível que seja capaz } \\
\text { de indicar. }\end{array}$ \\
\hline $\begin{array}{l}\text { ervolvidas com o } \\
\text { "mundo em } \\
\text { deserwolvimento". } \\
\text { Por outro lado, a } \\
\text { maioria das } \\
\text { feministas viram no } \\
\text { seu respectivo }\end{array}$ & $\begin{array}{l}\text { Movimento de "lita } \\
\text { geral" por justiça } \\
\text { social e poútica e } \\
\text { contra modelos de } \\
\text { "captalismo } \\
\text { selvagem" } \\
\text { impiantados por }\end{array}$ & $\begin{array}{l}\text { Estado-naç ấo acabou por se } \\
\text { integrar em alguns aspectos } \\
\text { com as necessidades } \\
\text { administrativas de uma nova } \\
\text { forma de capitalismo. }\end{array}$ & $\begin{array}{l}\text { Articulação } \\
\text { horizontalizada dos } \\
\text { feminismos latino- } \\
\text { americanos A ênfase } \\
\text { no Fórum Social } \\
\text { Mundial e na Marcha }\end{array}$ \\
\hline $\begin{array}{l}\text { Estado o lugar de } \\
\text { demandas para } \\
\text { seus interesses } \\
\text { próprios. }\end{array}$ & $\begin{array}{l}\text { militares, eikes } \\
\text { poriticas civis e aliados } \\
\text { imperialistas e das } \\
\text { classes dominantes } \\
\text { (ALVAREZ, 2000). }\end{array}$ & $\begin{array}{c}\text { Rápida absorção das idéias } \\
\text { feministas pelos Estados e } \\
\text { sociedades latino-americanas. }\end{array}$ & Mundial de Muheres. \\
\hline
\end{tabular}

FONTE: Elaboração da autora, a partir de Alvarez (2000) e Fraser (2009). 
Infelizmente, no arcabouço apenas deste artigo, seria impossível operar um detalhamento das considerações complexas que estão envolvidas neste quadro referencial. Esta será tarefa necessária para esforços teórico-analíticos posteriores. Com a apresentação, ainda que não tão detalhada, do quadro acima, apenas indico como me parece ser fértil a aposta numa "nova onda" feminista que venha articulada aos desafios contemporâneos do capitalismo, mas evitando-se o tratamento empobrecedor e reducionista destas fases por uma chave excessivamente norte-americana. Acredito, então, que o futuro para a noção dos desdobramentos feministas que se exercitaria no âmbito norte-americano já seria, pois, o atual presente latino-americano e brasileiro (assim como acredito que os desafios do Estado militarizado, que os feminismos norte-americanos estão atualmente combatendo, já foram enfrentados por nós), pois, a partir do governo Lula, o Brasil (bem) aos poucos vem sendo reestruturado como um Estado pós-neoliberal ${ }^{18}$, com a inclusão de parte dos movimentos sociais (ainda que alguns movimentos ainda se mantenham "autônomos"), inclusive os feministas.

$\mathrm{O}$ que acrescentamos ao esquema proposto por Fraser refere-se estritamente a uma crítica à hipótese defendida pela autora: não concordo que a difusão das idéias e atitudes culturais do feminismo tenha levado, exclusivamente, a uma transformação da sociedade capitalista "na direção oposta às visões feministas de sociedade justa" (FRASER, 2009, p. 99). A partir do Sul global, os feminismos têm reconstruído (e por completo) sua relação (sempre tensa e disputada) com o Estado e com o regime capitalista de produção.

Têm sido muitas as mudanças institucionais, econômicas e culturais nos países latino-americanos e em especial no Brasil nos últimos anos. Muitas delas são resultados inequívocos da participação feminina e feminista por meio dos movimentos sociais e políticos nos quais se engajaram no momento da transição do regime militar (ao

\footnotetext{
18 De acordo com recentes análises de conjuntura sobre o governo Lula, este poderia ser considerado como um governo pós-neoliberal e pragmático. Para Emir Sader (2009), a América Latina surgiu como "o" lugar onde se é possível contestar a "reinante" política neoliberal. No Brasil, as eleições de Lula seriam um indício para uma virada pósneoliberal.
}

longo dos anos 1960 e 1970) para a democratização do país (nos anos 1980). São resultados também de processos de institucionalização de demandas sociais combinados ao esforço de execução de outros formatos e desenhos de políticas públicas. Conceituamos tais tendências em curso como uma "quarta onda" do feminismo no país, que poderia, por sua vez, ser definida como um processo de "democratização de gênero no âmbito das instituições e da (re)formulação de políticas públicas", assim como de revitalização da agenda clássica do feminismo na busca por direitos, desta vez a partir dos desafios colocados pelo movimento contemporâneo de transnacionalização do feminismo, de globalização das agendas locais das mulheres e de fermentação das estratégias feministas horizontais.

Ao levantarmos os elementos centrais da agenda política das mulheres brasileiras nos anos 1970 e 1980, e ao compará-la depois com a pauta política dos anos 1990 em diante, recuperamos também o percurso de difusão assimétrica e desigual das bandeiras do feminismo no campo dos valores e das percepções nas relações cotidianas de gênero até a sua influência mais efetiva na transformação das reivindicações históricas em plataformas de fato, de intervenção no/do Estado. Para Alvarez (2000, p. 385-386), teria havido ao longo dos anos 1990 um “descentramento saudável do feminismo latino-americano", transformando-se este em um "campo de ação expansivo, policêntrico e heterogêneo que abarca uma vasta variedade de arenas culturais, sociais e políticas". Ainda, segundo Farah (2004), desde o final dos anos 1970, também ocorreram transformações significativas nas relações entre Estado e sociedade no Brasil, especialmente a partir de dois grandes "condicionantes": o processo da democratização e o de crise fiscal do Estado. Segundo a autora: "Ao lado da mudança de regime, após mais de 20 anos de regime ditatorial, os anos 1980 foram também marcados pela crise do nacional desenvolvimentismo, de origens mais antigas, assim como por mudanças nas políticas públicas, estabelecidas ao longo das décadas anteriores" (FARAH, 2004, p. 49).

O que mais se destacou na pauta das reivindicações das muitas organizações feministas e de mulheres naquele momento foram, então, as necessidades e premências justamente da vida cotidiana, bem como aquelas urgências nascidas das utopias de esquerda que, com muita certeza, pau- 
taram a agenda que surgia. Parcelas significativas dos movimentos de mulheres dos anos $1970 \mathrm{em}$ diante, no Brasil, nasceram dos grupos de vizinhança nas periferias dos grandes centros urbanos. As mulheres dos bairros populares passaram a construir sua dinâmica política própria: ainda que basicamente permeadas pelos papéis socialmente designados de "esposas" e "mães", elas cumpriram o importante papel político de organizar parte significativa dos primeiros protestos contra o regime militar (SIMÕES, 1985).

Soares (1998, p. 36) vai nos chamar a atenção para o fato de que, para além do feminismo em si, a denominação "movimento de mulheres" abarcava um conjunto mais ampliado de grupos femininos que lutavam por temas que se relacionavam ao universo simbólico e material de referência das mulheres, nem todos declaradamente "feministas" (a exemplo dos grupos vinculados às Comunidades Eclesiais de Base da Igreja Católica). Foi em momento específico do país, quando parte substantiva dos grupos de esquerda se encontrava combalido e enfraquecido, que a reação política partiu do lugar inesperado - os novos movimentos sociais e as organizações políticas lideradas por mulheres.

Tratava-se neste momento também, não apenas de visar a mudanças no regime político, mas na estrutura interna do próprio Estado e em suas ações, de modo a superar características críticas do padrão de intervenção estatal anterior ${ }^{19}$. Foi, assim, acrescentado ao esquema proposto por Fraser - como representando o período da segunda "onda" feminista latino-americana e brasileira - o momento de resistência e luta contra os Estados militarizados ditatoriais, sendo que foi

\footnotetext{
19 Farah destaca as seguintes as características de organização do Estado brasileiro neste período anterior aos anos 1980: “a) centralização decisória e financeira na esfera federal; b) fragmentação institucional; c) gestão das políticas sociais a partir de uma lógica financeira levando à segmentação do atendimento e à exclusão de amplos contingentes da população do acesso aos serviços públicos; d) atuação setorial; e) penetração da estrutura estatal por interesses privados; f) condução das políticas públicas segundo lógicas clientelistas; g) padrão verticalizado de tomada de decisões e de gestão e burocratização de procedimentos; h) exclusão da sociedade civil dos processos decisórios; i) opacidade e impermeabilidade das políticas e das agências estatais ao cidadão e ao usuário; j) ausência de controle social e de avaliação" (FARAH, 2004, p. 50).
}

apenas a partir dos anos 1980 que os movimentos sofreram processo de ampliação e também de diversificação, desta vez adentrando necessariamente nos partidos políticos, nos sindicados e nas associações comunitárias. Como será possível perceber mais adiante, tais grupos não conseguiram conquistar lugar no espaço público institucionalizado brasileiro (a exemplo do Parlamento), mas as suas articulações, certamente, incumbiram-se de expandir as fronteiras da discussão para diversos cantos do país e ajudaram a refundar valores e reinventar padrões e representações de gênero, tendo como objetivo primordial revelar as negligências do governo em relação às graves desigualdades sociais e econômicas da nossa sociedade.

Ainda que o feminismo brasileiro (e mesmo latino-americano) deste momento tenha se caracterizado por dar as costas ao Estado e suas arenas políticas convencionais (ALVAREZ, 2000), no intuito de trazer à tona e problematizar aqueles temas ligados às "problemáticas das mulheres", houve um primeiro momento de convergência dos movimentos urbano-populares com o movimento feminista, naquele momento que estamos caracterizando como de "terceira" onda feminista. As forças foram unificadas no objetivo central da transformação da situação da mulher na sociedade brasileira, gestada durante os regimes militares, e colocada à prova no momento da redemocratização do país. Tanto o movimento feminista quanto os demais movimentos sociais urbanos, naquilo que tange aos temas específicos das mulheres, somaram as forças para conquistar a inclusão da temática de gênero na agenda pública e estatal. É desta forma que é possível afirmar que a luta pela superação das desigualdades de gênero no país buscaram "tanto uma crítica à ação do Estado quanto - à medida que a democratização avançava - a formulação de propostas de políticas públicas que contemplassem a questão de gênero" (FARAH, 2004, p. 51).

Por um lado, Alvarez (2000, p. 388) analisa que "ao reagir às instituições excludentes e amiúde repressivas do regime e ao 'centralismo democrático' das esquerdas, as feministas criaram uma política cultural distintiva que valorizava as práticas democráticas radicais e a autonomia de organização". Em contrapartida, segundo Farah, tal nova agenda do feminismo, surgida nos idos dos anos 1990, teria sido marcada pela "tensão permanente entre o vetor 'eficiência' e o vetor 'de- 
mocratização dos processos decisórios e do acesso a serviços públicos"'. Essa tensão, por sua vez levaria a uma disputa permanente: os "movimentos populares, partidos à esquerda no espectro político e governos de corte progressista tendem a privilegiar a democratização das decisões e a inclusão social; partidos e governo de corte liberal-conservador e organizações da sociedade civil ligadas às elites empresariais tendem a privilegiar a orientação para a eficiência e corte de gastos, o que significa, na área social, privatização, focalização e modernização gerencial como prioridades" (FARAH, 2004, p. 52-53).

Multiplicaram-se, então, as modalidades de organizações e identidades feministas. As mulheres pobres articuladas nos bairros por meio das associações de moradores, as operárias por meio dos departamentos femininos de seus sindicatos e centrais sindicais, as trabalhadoras rurais por meio de suas várias organizações começaram a se identificar com o feminismo, o chamado feminismo popular. As organizações feministas de mulheres negras seguiram crescendo e ampliando a agenda política feminista e os parâmetros da própria luta feminista. Esse crescimento do feminismo popular trouxe, como conseqüência fundamental, um pouco da diluição das barreiras e resistências ideológicas em relação ao feminismo. Tal diversidade do feminismo brasileiro esteve presente nos preparativos da Quarta Conferência Mundial sobre a Mulher (QCMM), realizada em setembro de 1995, em Beijing, China, ao incorporar amplos setores do movimento de mulheres do país.

O alvorecer do século XXI traz para o movimento feminista o tema da participação política das mulheres nas esferas de decisão do Estado, no âmbito do continente latino-americano, passando a entender a participação paritária institucional como um dos espaços mais importantes - e ainda intocados - rumo a uma sociedade mais equânime no que tange às questões de gênero. Gostaria, pois, de destacar que o tema do acesso das mulheres aos espaços da representação com participação passou a ocupar significativa presença na agenda das pesquisas e dos movimentos feministas na última década, representando mais do que um deslocamento e sendo a percepção de que a participação política e a atuação dentro das esferas do Estado é uma estratégia de grande importância para a busca de uma soci- edade mais justa, levando-se em conta os instrumentos de controle e políticas públicas que visem à reparação de desigualdades de modo mais eficaz que as velhas formas de manifestação. É claro também que, mesmo que de um lado tenhamos uma guinada do movimento rumo à participação política mais significativa, temos também e principalmente as novas configurações do Estado que permitem que as reivindicações - antes não canalizadas - passem a encontrar ouvidos atentos que nos idos dos anos 1970 não estavam presentes da forma como hoje se apresentam.

Tem sido por meio de muita sensibilidade em relação às dinâmicas do poder e da necessidade de se lutar mais por ele e menos por uma agenda de direitos, que passou a ser possível prenunciar o começo expressivo de um gigantesco esforço de transversalização das forças de todos os matizes dos feminismos da região. Já no final dos anos 1990 e início dos anos 2000, um número crescente de feministas começa a enxergar nos partidos políticos, nos órgãos dos poderes Legislativo e Executivo, espaços potencialmente viáveis para a atuação feminista. Se erigindo como algo que pode ser descrito como um movimento multinodal de mulheres ou a partir de diferentes "comunidades de políticas de gênero" (como tem sido mais comum se referir no Brasil), o feminismo, em parte significativa dos países da região latino-americana, na atualidade, não só foi transversalizado estendendo-se verticalmente por meio de diferentes níveis do governo, atravessando a maior parte do espectro político e engajando-se em uma variedade de arenas políticas aos níveis nacionais e internacionais -, mas também se estendeu horizontalmente, fluiu horizontalmente ao longo de uma larga gama de classes sociais, de movimentos que se mobilizam pela livre expressão de experiências sexuais diversas e também no meio de comunidades étnico-raciais e rurais inesperadas, bem como de múltiplos espaços sociais e culturais, inclusive em movimentos sociais paralelos.

A heterogeneidade crescente passou a caracterizar os feminismos da região latino-americana (ALVAREZ, 2000), conformando-se no momento que estou tentando defender como expressivo de uma "quarta" onda feminista. A difusão feminista, com certeza, tem produzido muitas conseqüências políticas e culturais por meio de muitos caminhos e já é possível identificar casos: o do Sindicato dos Bancários no Brasil, por exemplo, 
em que grupos de mulheres dentro de um movimento de classe empreenderam a luta desde dentro para influir no próprio movimento; encontros entre o feminismo acadêmico e alunas de cursos de capacitação política para mulheres candidatas na esfera político-legislativa; e também seria possível incluir as piqueteras e os Encuentros Nacionales de Mujeres (ocorrendo anualmente na Argentina e que contam com a participação de mais de 20000 mulheres); o movimento estudantil e, possivelmente, o Mapuche e/ou os movimentos ambientais no Chile; movimentos indígenas e grupos LGBTs (Lésbicas, Gays, Bissexuais e Transgêneros) no Peru; o movimento de mulheres rurais; as Promotoras Legais Populares; a Central Única dos Trabalhadores (CUT); o Movimento dos Trabalhadores Rurais Sem-Terra (MST); os movimentos negros; o Partido dos Trabalhadores (PT) "de base"; assim como também as Conferências Nacionais de Políticas para as Mulheres no Brasil, que reuniram, em 2004 e 2007, mais de 3000 mulheres.

Num outro regime de esforços é possível também perceber a tentativa de produção de encontros regionais feministas que desobedecem a lógica hegemônica e tradicional "do centro para a periferia" ou do "Norte para o Sul": refiro-me aqui especialmente a estratégias como o Fórum Social Mundial em nível regional e em sintonia com todos os países do Sul e a recente criação da Universidade Popular dos Movimentos Sociais (UPMS) (SANTOS, 2008), que se realizou em 2009, por meio de oficinas e ações implementadas recentemente no Brasil pelo Centro de Estudos Sociais da América Latina (CES-AL). A UPMS Rede Global de Saberes é um espaço de formação intercultural que promove um processo de interconhecimento e auto-educação com o duplo objetivo de aumentar o conhecimento recíproco entre os movimentos e organizações e tornar possíveis coligações entre eles e ações coletivas conjuntas. Ela também se constitui em um espaço aberto para o aprofundamento da reflexão, o debate democrático de idéias, a formulação de propostas, a troca livre de experiências e a articulação para ações eficazes, de entidades, de cientistas sociais e movimentos sociais locais, nacionais e globais que se opõem ao neoliberalismo e que desejam apostar na possibilidade de se reconstruir o próprio saber científico. Este segundo conjunto de esforços muito recentes visa a consolidar articulações político-institucionais entre países e fe- ministas, a partir de ações estruturadas no Sul e numa lógica de operação global "de baixo para cima", ou seja, gerida no Sul e direcionada para o Sul.

Mesmo com o avanço propiciado por Fraser ao propor um modelo tridimensional da justiça social e com as críticas pertinentes de Mohanty, ainda faz-se necessário uma aposta em avanços teóricos significativos, explicitando aspectos subentendidos que não foram ainda tratados justamente devido a organizações epistemológicas reducionistas que não os incluem nas formas de teorização, principalmente aqueles relativos à experiência e prática do feminismo latino-americano. Por isso, a proposta de uma teoria críticoemancipatória feminista e de gênero, a qual me dediquei em outro momento (MATOS, 2009a; $2009 b)^{20}$, à luz da crítica epistêmica, propôs um conjunto de elementos que seriam considerados cruciais quando se pretende uma forma de teorização para além dos paradigmas dialéticos e binarizantes, bem como culturalmente reduzidos (principalmente ao Ocidente, neste caso). Tal proposta avança em direção a se pensar os eixos estruturadores da justiça social numa dimensão significativamente ampliada, inclusive numa perspectivação analítica que destaca a dimensão paradoxal e simultânea de repor igualdade e diferença num regime de complexidade, propondo realocar uma das principais contendas no feminismo latino-americano (e também nos feminismos de outras regiões), que seria, segundo Schutte (1998), o debate entre feministas igualitárias e os feminismos da diferença. O sentido orientador da nova "onda", também para os estudos e teorias feministas, está vinculado, em meu entender, a uma renovada ênfase em fronteiras interseccionais, transversais e transdisciplinares entre gênero, raça, sexualidade, classe e geração (no jargão de Fraser: nas transfronteiras). Também tem débito incontestável com a necessidade de transversalização

\footnotetext{
20 Impossível, neste artigo, discorrer com o cuidado e a profundidade necessários sobre a proposta completa deste novo modelo. Importa salientar, contudo, que o mesmo tem sua origem na minha própria trajetória inter ou transdiciplinar entre os campos da Psicologia e Psicanálise, Sociologia e Ciência Política, e enfatiza sobremaneira dinâmicas epistêmicas, filosóficas e teóricas críticas aos binarismos de todas as ordens, enfatizando a multidimensionalidade, a complexidade, os paradoxos e a simultaneidade (cf. MATOS, 2009a; 2009b).
} 
do conhecimento e a transversalidade na demanda por direitos (humanos) e justiça social e implica: 1) o alargamento da concepção de direitos humanos (a partir da luta do feminismo e das mulheres); e 2) a ampliação da base das mobilizações sociais e políticas. Por exemplo, a Marcha Mundial das Mulheres (MMM) - movimento que pode ser considerado emblemático do feminismo de "quarta" onda - teve origem numa manifestação pública feminista no Canadá, em 1999, cujo lema, inspirado em uma simbologia feminina - "pão e rosas" -, expressava a resistência contra a pobreza e a violência. Mantém até hoje esse primeiro mote, mas vem ampliando sua conotação, convocando o conjunto dos movimentos sociais para a luta por "um outro mundo" (designada de "altermundialismo"), e por novos direitos humanos, em que sejam superados os legados históricos do patriarcalismo e do capitalismo, conforme registrado na "Carta Mundial das Mulheres para a Humanidade" (MARCHA MUNDIAL DE MULHERES, 2005, p. 6): "Esses sistemas se reforçam mutuamente. Eles se enraízam e se conjugam com o racismo, o sexismo, a misoginia, a xenofobia, a homofobia, o colonialismo, o imperialismo, o escravismo e o trabalho forçado. Constituem a base dos fundamentalismos e integrismos que impedem às mulheres e aos homens serem livres. Geram pobreza, exclusão, violam os direitos dos seres humanos, particularmente os das mulheres, e põem a humanidade e o planeta em perigo".

A luta, portanto, pela transversalidade dos direitos humanos, expressa na Carta, possui cinco valores de referência: igualdade, liberdade, solidariedade, justiça e paz; ou seja, a MMM pretende ocupar o espaço de uma organização feminista transnacional baseada nas lutas antiracistas e antimachistas e dos ativismos antiglobalização, conforme insistiu Mohanty. Tais bandeiras transformaram-se em reivindicações coletivas da Marcha e tem sido em torno delas que a MMM não só consegue se comunicar com o conjunto das tendências do feminismo contemporâneo, dos movimentos de mulheres de base local e global, mas também com outros movimentos sociais, com outras especificidades e simpatizantes de suas causas, formando uma rede global de redes de movimentos, identidades plurais, radicalizando a democracia, a partir dos níveis locais, regionais, nacionais, até os transnacionais, na direção de uma cidadania que se propõe planetária.
A ampliação dos direitos humanos das mulheres, por sua vez, nunca esteve tão evidente como nas determinações referentes à incorporação da perspectiva de gênero (gender mainstreaming) pelas conferências mundiais, a exemplo de Viena e Beijing. De fato, ao mesmo tempo que a diferença deixa de ser uma justificativa para a exclusão do gênero dos principais discursos sobre direitos humanos, ela, em si mesma, passou a servir de apoio à própria lógica de incorporação da perspectiva de gênero. Tal incorporação baseouse na visão de que, sendo o gênero importante, seus efeitos diferenciais precisam ser analisados no contexto de todas as atividades relativas aos direitos humanos. Assim, enquanto no passado, a diferença entre mulheres e homens serviu de justificativa para marginalizar os direitos das mulheres e, de modo mais geral, para justificar as desigualdades de gênero, atualmente a diferença das mulheres indica a responsabilidade que qualquer instituição de direitos humanos teria de incorporar uma análise de gênero em suas práticas e análises teóricas (é a essa difusão teórico-cultural que reputo importância como uma nova fase dos estudos no campo de gênero e feminista).

A luta feminista (e também a luta por direitos humanos), em sua "quarta" onda, também reforça o princípio da não-discriminação com base na raça, etnia, nacionalidade ou religião. Essa garantia foi elaborada na Convenção Internacional para a Eliminação de Todas as Formas de Discriminação Racial (International Convention on the Elimination of All Forms of Racial Discrimination - CERD), que tratou da proteção contra a discriminação baseada na cor, na descendência e na origem étnica ou nacional. No sentido de melhor definir o alcance do direito à não-discriminação racial, associada à não-discriminação de gênero, foram feitos muitos esforços em conferências mundiais, oportunidade que se apresentou na Conferência Mundial contra o Racismo, Discriminação Racial, Xenofobia e Intolerâncias Correlatas, em Durban, na África do Sul. No entanto, nada equivalente aos compromissos assumidos em Viena e Beijing, em termos da incorporação de gênero, foi conquistado ou consolidado no contexto da raça e discriminação racial. Foi assim que estudos feministas passaram, então, a lançar mão do conceito de interseccionalidade, inicialmente introduzido por K. Crenshaw (1989) numa discussão a respeito do desemprego das mulheres 
negras nos EUA (tendo sido convidada a apresentar tal noção em sessão especial em Genebra, no encontro preparatório da Conferência Mundial sobre o Racismo, em 2001, em Durban), para comprometer uma agenda de reivindicações compartilhadas entre gênero e raça. $\mathrm{O}$ debate internacional e também os debates regionais, no final da década de 1990, como visto em Mohanty, foram marcados pelo surgimento de categorias analítico-teóricas que aludiam à multiplicidade de diferenciações, que, articulando-se a gênero, permeariam o social: dentre estas, estão, é claro, as categorias de articulação e interseccionalidade (intersectionality). Algumas autoras optam por um desses conceitos (MCKLINTOCK, 1995; CRENSHAW, 2002). Outras utilizam alternativamente ambos (BRAH, 2006). Foi na década de 2000 que a utilização dessas categorias ficou amplamente difundida. Contudo, assim como aconteceu com o conceito de gênero, elas adquiriram conteúdos diferentes segundo as abordagens teóricas das autoras. Mas, segundo Crenshaw, as interseccionalidades são formas de capturar as conseqüências da interação entre duas ou mais formas de subordinação: sexismo, racismo, patriarcalismo. Essa noção de "interação" entre formas de subordinação possibilita superar a noção simplificada de superposição de opressões.

Em relação ao Estado e às dinâmicas vinculadas a este novo formato de teorização feminista, destaca-se, por sua vez, o esforço no sentido de ações transversais e intersetoriais. Uma nova forma teórica - transversal e interseccional - de compreensão dos fenômenos de raça, gênero, sexualidade, classe e geração desdobram-se na necessidade de se pensar em micro e macroestratégias de ação articuladas, integradas, transversais e intersetoriais, construídas em conjunto pelo Estado e pela sociedade civil. Os esforços, considerados cada um desses componentes em sua dinâmica de articulação complexa (e, às vezes, paradoxal), tornam-se mais profícuos para a resolutividade das questões sociais com as quais nos deparamos na atualidade. No caso brasileiro, sabemos que, na execução das políticas, por exemplo, tradicionalmente, poucas vezes tais temas são tratados de modo transversal e interseccional e se busca realmente estabelecer diálogo entre os diferentes setores envolvidos na promoção das ações governamentais. Entendo que está em construção uma perspectiva mais aprofundada sobre a transversalidade e a intersetorialidade nas políti- cas públicas, não como mera utopia ou elocubração teórica, já que algumas experiências brasileiras vêm se destacando nesse campo e mostram que, aos poucos, com dificuldades - e lições aprendidas -, a intersetorialidade e a transversalidade são formas de gestão possíveis e mesmo mais eficientes em termos da promoção do desenvolvimento social e econômico do país e de garantia do atendimento integral aos direitos humanos. Há muito ainda a se explorar sobre como um novo modelo de teoria crítica feminista pode vir a contribuir no avanço da democracia e da justiça em tempos globalizados. E este artigo apenas indicou para esta riqueza de possibilidades, sem se aprofundar efetivamente nela. Deixamos este aprofundamento para outro momento.

\section{CONSIDERAÇÕES FINAIS}

Os desafios que o feminismo contemporâneo enfrenta vão muito além das fronteiras dos Estados nacionais - territórios que o movimento feminista estaria ultrapassando ou mesmo borrando, de um modo que acredito ser definitivo. Percebo uma orientação na direção da superação de limites outros que não se restringem mais a demarcações e restrições tradicionais - dentro do feminismo, dentro de um território nacional, dentro de um lugar específico para as ações estatais, no sentido do Norte para o Sul - que impõe um grau de alcance para as lutas e ações políticas dos movimentos que é absolutamente inédita para os parâmetros da nossa modernidade (mesmo que tardia). É pela primeira vez que se faz possível e até palpável vislumbrar e reconhecer a idéia do fluxo, do trânsito movimentalista em uma perspectiva crítica entre pensamento e práxis feminista na virada de uma "quarta" onda. Quem sabe com esse outro inovador dinamismo não seja mais concretizável o sonho da superação das injustiças que ainda corroem esse nosso mundo. A análise apresentada brevemente neste ensaio certamente não esgota o debate acerca da multidimensionalidade analítica adotada sob um viés crítico-feminista do campo de gênero e das inovadoras recentes estratégias de difusão feminista, mas certamente tentou ainda que brevemente expor o quanto tais deslocamentos tornaram possível antever um futuro mais promissor.

O que se delineou aqui é tanto o esforço quanto o "acerto de contas" de milhares e milhares de mulheres que, na opressão, invisibilidade e silêncio (outras nem tanto), vêm buscando fundar, 
construir e solidificar as condições de possibilidade de um jogo político e científico que não se faça de modo reducionista, enviesado, infértil, descomprometido e limitado. O quadro e a figuração aqui apresentados estão permanentemente em aberto, porosos, sujeito a complementações e/ou suplementações. Trata-se de uma proposta em contínuo re/desfazimento de si mesma. Ousar também pode se constituir numa maneira crítica de produzir a "boa ciência" e a "boa política" (e, por que não também, a "boa Ciência Política").

É sabido que o campo feminista de gênero tem nos oferecido ferramentas teóricas e reflexões metodológicas substantivas que já são responsáveis pela formação de algumas gerações de pen- sadores acadêmicos e de intelectuais. Penso que este forte avanço no sentido da concretização da institucionalização deste novo campo e da concomitante associação para a construção de uma "quarta" onda feminista, além de produzir a sua visibilização e reforçar a sua consolidação, vai contribuir concretamente nas muitas revisões, reelaborações e visibilizações de questões que são centrais atualmente e que ainda não tivemos tempo suficiente para deflagrar. O espaço está conquistado e necessita ser definitivamente consolidado, mantido e até ampliado. Mas, olhando para trás, parece-me inegável que aquelas e aqueles que, como eu, fizeram parte deste caminhar, tenham muito mais a comemorar do que a lastimar.

Marlise Matos (marlise.matos@fafich.ufmg.br) é Doutora em Sociologia pelo Instituto Universitário de Pesquisas do Rio de Janeiro (Iuperj) e Professora na Universidade Federal de Minas Gerais (UFMG).

\section{REFERÊNCIAS BIBLIOGRÁFICAS}

ALVAREZ, S. E. 1989. The (Trans)Formation of Feminism and Gender Politics in Democratizing Brazil. In: JAQUETTE, J. S. (ed.). The Women's Movement in Latin America. Bolder: Westview.

1990. Engendering Democracy in Brazil: Women's Movements in Transition Politics. Princeton: Princeton University.

1998. Feminismos latinoamericanos. Revista Estudos Feministas, Florianópolis, v. 6, n. 2, p. 265-284.

2000. A "globalização" dos feminismos latino-americanos: tendências dos anos $90 \mathrm{e}$ desafios para o novo milênio. In: ALVAREZ, S. E.; DAGNINO, E. \& ESCOBAR, A. (orgs.). Cultura e política nos movimentos sociais latino-americanos: novas leituras. Belo Horizonte: UFMG.

.2009a. Beyond NGO-ization? Reflections from Latin America. Development, Rome, n. 52 , p. $175-184$.

2009b. Construindo uma política feminista translocal da tradução. Revista Estudos Feministas, Florianópolis, v. 17, n. 3, p. 743753. Disponível em: http://www.scielo.br/ scielo.php?pid=S0104-026X2009000300007 \&script=sci_arttext. Acesso em: 1.mai.2010.
ALVAREZ, S. E.; FRIEDMAN, E. J.; BECKMAN， E.; BLACKWELL，M.; CHINCHILLA, N. S.; LEBON, N.; NAVARRO, M. \& TOBAR, M. R. 2003. Encontrando os feminismos latino-americanos e caribenhos. Revista Estudos Feministas, Florianópolis, v. 11, n. 2, p. 541-575. Disponível em: http://www.periodicos.ufsc.br/ index.php/ref/article/viewFile/9919/9133. Acesso em: 1.mai.2010.

BLAY, E. A. 1984. A participação das mulheres na redemocratização. São Paulo: Conselho Estadual da Condição Feminina.

BRABO, T. S. A. M. 2006. A pedagogia do Movimento Feminista na luta contra o preconceito e pelos direitos das mulheres. In: Anais do Seminário Internacional Fazendo Gênero. Florianópolis: UFSC.

BRAH, A. 2006. Diferença, diversidade, diferenciação. Cadernos Pagu, Campinas, n. 26, p. 329-365. Disponível em: http://www.scielo.br/ pdf/cpa/n26/30396.pdf. Acesso em: 1.mai.2010.

COSTA, A. 2005. O movimento feminista no Brasil: dinâmicas de uma intervenção política. Labrys, Brasília, n. 7. 
CRENSHAW, K. 1989. Demarginalizing the Intersection of Race and Sex: a Black Feminist Critique of Antidiscrimination Doctrine, Feminist Theory and Antiracist Politics. University of Chicago Legal Forum, Chicago, p. 139-167.

CYPRIANO, B. 2010. Sobre algumas das contribuições feministas ao conhecimento politico: "a" política, "o" político e enquadramentos teóricos da Justiça Social. Belo Horizonte. Dissertação (Mestrado em Ciência Política). Universidade Federal de Minas Gerais.

DIRLIK, A. 1999. Place-Based Imagination: globalism and the Politics of Place. Review, Binghamton, v. 22, n. 2.

ESTEVA，G. \& PRAKASH，M. S. 1998. Grassroots Postmodernism: Remaking the Soil of Cultures. London: Zed.

FARAH, M. F. S. 2004. Gênero e políticas públicas. Revista Estudos Feministas, Florianópolis, v. 12 , n. 1 , p. $47-71$.

FRASER, N. 1995. O que é crítico na teoria crítica? $\mathrm{O}$ argumento de Habermas e gênero. In: BENHABIB, S. \& CORNELL, D. (orgs.). $\mathrm{Fe}$ minismo como crítica da modernidade: releitura dos pensadores contemporâneos do ponto de vista da mulher. Rio de Janeiro: Rosa dos Tempos.

1999. Repensando la esfera pública: una contribución a la crítica de la democracia actualmente existente. Revista Ecuador Debate, n. 46.

2001. Da redistribuição ao reconhecimento? Dilemas da justiça na era pós-socialista. In: SOUZA, J. (org.). Democracia hoje: novos desafios para a teoria democrática contemporânea. Brasília: UNB.

2005a. Reframing justice. Amsterdam: Royal Van Gorcum.

2005b. Reframing Justice in a globalizing world. New Left Review, London, n. 36, p. $69-88$

.2007a. Abnormal Justice. In: APPIAH, K. A. Justice, Governance, Cosmopolitanism, and the Politics of Difference: Reconfigurations in a transnational World. Berlin: Der Präsident der Humboldt-Universität zu Berlin. 2007b. Mapeando a imaginação feminista: da redistribuição ao reconhecimento e à representação. Revista Estudos Feministas, Florianópolis, v. 15, n. 2, p. 291-308.

2008. Scales of Justice: Reimagining Political Space in a Globalizing World (new Directions in Critical Theory). New York: Columbia University.

2009. Feminism, Capitalism and the Cunning of History. New Left Review, London, n. 56, p. 97-117.

GUZMÁN, V. 2001. La instituciuonalidad de género em el Estado : nuevas perspectivas de análisis. Santiago de Chile : Organización de las Naciones Unidas. Disponível em: http:// www.eclac.org/publicaciones/xml/3/6323/ 1c11511e.pdf. Acesso em: 5.mai.2009.

HABERMAS, J. 1984. Mudança estrutural da esfera pública: investigações quanto a uma categoria da sociedade burguesa. Rio de Janeiro: Tempo Brasileiro.

HEILBRON, M. L. \& ARRUDA, A. 1995. Legado feminista e ONGs de mulheres: notas preliminares. In: NÚCLEO DE ESTUDOS DA MULHER E POLÍTICAS PÚBLICAS. Gênero e Desenvolvimento institucional em ONGs. Rio de Janeiro: IBAM.

HELD, D. \& KAYA, A. 2007. Global Inequality: Patterns and Explanations. Cambridge: Polity.

MCCLINTOCK, A. 1995. Imperial Leather: Race, Gender and Sexuality in the Colonial Contest. New York: Routledge.

MIGUEL, L. F. 2005. Teoria democrática atual: esboço de mapeamento. BIB, São Paulo, n. 59 , p. 5-42.

MATOS, M. 2008. Teorias de gênero e teorias e gênero? Se e como os estudos de gênero e feministas se transformaram em um campo novo para as ciências. Revista Estudos Feministas, Florianópolis, v. 16, n. 2, p. 333-357. Disponível em: http://socialsciences.scielo.org/ s c i e 1 o.p h p ? p i d = S 0104 026X2008000100005\&script $=$ sci_arttext. Acesso em: 1.mai.2010.

2009a. Desdobramentos das agendas dos feminismos contemporâneos: a quarta onda. In: MATOS, M. (org.). Enfoques feministas e 
os desafios contemporâneos. V. I. Debates acerca do feminismo: antigos e novos desafios. Belo Horizonte: UFMG.

2009b. Em busca de uma teoria críticoemancipatória feminista de gênero: reflexões a partir da experiência da política na ausência das mulheres. In: MATOS, Marlise. (org.). Enfoques feministas e os desafios contemporâneos: perspectiva feminista de gênero na política e nas políticas públicas. Belo Horizonte: UFMG.

MOHANTY, C. T. 1984. Under Westerns Eyes: Feminist Scholarship and Colonial Discourses. Boundary 2, Durham, v. 12, n. 3, p. 333-358.

2003. Feminism Without Borders: Decolonizing Theory, Practicing Solidarity. Durhan: Duke University.

2006. US Empire and the Project of Women's Studies: Stories of Citizenship, Complicity and Dissent. Gender, Place and Culture, London, v. 13, n. 1, p. 7-20.

PINTO, C. R. J. 1994. Participação (representação?) política da mulher no Brasil: limites e perspectivas. In: SAFFIOTI, H. \& MUÑOZVARGAS, M. (orgs.). Mulher brasileira é assim. Rio de Janeiro: Rosa dos Tempos.

2003. Uma história do feminismo no Brasil. São Paulo: Fundação Perseu Abramo.

RAWLS, J. 2002. Uma teoria da Justiça. São Paulo: M. Fontes.

RIBEIRO, M. 2006. O feminismo em novas rotas e visões. Revista Estudos Feministas, Florianópolis, v. 14, n. 3, p. 801-811. Disponível em: http://www.scielo.br/pdf/ref/v14n3/ a12v14n3.pdf. Acesso em: 1.mai.2010.

SADER, E. 2009. A nova toupeira: os caminhos da esquerda latino-americana. São Paulo: Boitempo.

SAFFIOTI, H. I. B. 1976. A mulher na sociedade de classes: mito e realidade. Petrópolis: Vozes.

SAFFIOTI, H. \& MUÑOZ-VARGAS, M. (orgs.) 1994. Mulher brasileira é assim. Rio de Janeiro: Rosa dos Tempos.

SANTOS, B. S. 2008. A gramática do tempo: para uma nova cultura política. São Paulo: Cortez.
SCHOTT, R. 1996. Eros e os processos cognitivos: uma crítica da objetividade em filosofia. Rio de Janeiro: Rosa dos Tempos.

SCHUMAHER, S. 2005. Panorâmica dos 30 anos de feminismo no Brasil. Sexualidade, Gênero e sociedade, Rio de Janeiro, v. 12, n. 23-2425, p. 1-3.

SCHUMAHER, M. A. \& VARGAS, E. 1993. Lugar no governo: álibi ou conquista? Revista Estudos Feministas, Florianópolis, v. 1, n. 2, p. 348-364.

SCHUTTE, O. 2000. Latin America. In: JAGGAR, A. M. \& YOUNG, I. M. (eds.). A Companion to Feminist Philosophy. Malden: Blackwell.

SIMÕES, S. D. 1985. Deus, pátria e família: as mulheres no golpe de 1964. Petrópolis: Vozes.

SOARES, V. 1998. Muitas faces do feminismo no Brasil. In: BORBA, A.; FARIA, N. \& GODINHO, T. (orgs.). Mulher e politica: gênero e feminismo no Partido dos Trabalhadores. São Paulo: Fundação Perseu Abramo.

TELES, M. A. 1993. Breve história do feminismo no Brasil. São Paulo: Brasiliense.

VARGAS VALENTE, V. 2002. Los feminismos latinoamericanos en su tránsito al nuevo milenio (una lectura político personal). In: MATO, D. (coord.). Estudios y otras prácticas intelectuales latinoamericanas en cultura $y$ poder. Caracas: Consejo Latinoamericano de Ciencias Sociales.

WALBY, S. 2000. Beyond the Politics of Location: the Power of Argument in a Global Era. Feminist Theory, Newcastle, v. 1, n. 2, p. 189-206.

YOUNG, I. M. 2000a. Inclusion and Democracy. Oxford: Oxford University.

2000b. La justicia y la política de la diferencia. Madrid: Cátedra.

2007. Global Challenges: War, Self Determination and Responsibility for Justice. Cambridge: Polity.

2009. Categorias desajustadas: uma crítica à teoria dual de sistemas de Nancy Fraser. Revista Brasileira de Ciência Política, Brasília, v. 1, n. 2, p. 193-214. Disponível em: http:// rbcp.unb.br/artigos/rbcp-n2-24.pdf. Acesso em: 1.mai.2010. 


\section{OUTRAS FONTES}

BRASIL. 2004. Plano Nacional de Politicas para as Mulheres. Brasília: Secretaria Especial de Políticas para Mulheres.
MARCHA MUNDIAL DE MULHERES. 2005.

Carta Mundial das Mulheres para a Humanidade. Disponível em: http:// www.esplar.org.br/artigos/maio/25.htm. Acesso em: 1.mai.2010. 
THE MOVEMENT AND FEMINIST THEORY: IS IT POSSIBLE TO RECONSTRUCT FEMINIST THEORY BEGINNING FROM THE GLOBAL SOUTH?

\section{Marlise Matos}

Taking Nancy Fraser's theoretical trajectory as my point of departure, this text takes recent paths in feminist theory as emblematic in the elaboration of a vigorous theoretical and analytical framework for the development of contemporary feminist theories and theories of justice. Yet the latter have been anchored in the hegemonic considerations of the global North. In this regard, Fraser, as a theoretician from the United States, has developed her thought at a certain distance from the most recent agendas of global feminism (and in particular, from the feminisms of the South) and thus, her reflections show an excessive bias "from a Western perspective". This perception leads me back to the critique of studies done in the Anglo-Saxon tradition, particularly through C. T. Mohanty's contributions in this vein. Lastly, I propose the experience of a "fourth wave" in feminist movements and studies in Brazil and Latin America, through feminist circuits of dissemination that operate via horizontal feminist currents - Black, academic, lesbian, male, etc.

KEYWORDS: Feminist movement and theory; justice; political participation; transversality; gender intersectionality. 
LE MOUVEMENT ET LA THÉORIE FÉMINISTE : SERAIT-IL POSSIBLE DE RECONSTRUIRE LA THÉORIE FÉMINISTE À PARTIR DU SUD GLOBAL ?

\section{Marlise Matos}

En partant de la trajetoire théorique de Nancy Fraser, le texte reprend la récente évolution de la théorisation féministe autant qu'emblématique de l'élaboration d'une étude théorique et analytique de souffle dans les démarches des théories contemporaines de la justice et du féminisme, ancré cependant, sur des considerations monopolisées par le Nord global. Il y a, dans ce sens, un « eloignement» de la théorie américaine par rapport aux agendas les plus récents du féminisme mondial (et en particulier ceux des féminismes du Sud), et une réflexion excessivement basée sur un « regard depuis l'Occident ». C'est à partir de cette constatation que je récupère la critique aux études de matrice anglo-saxone, à partir de la contribution de C. T. Mohanty. A la fin, je propose l'expérience d'une « quatrième vague » des mouvements et études féministes au Brésil et en Amérique Latine, en montrant des circuits de diffusion féministe opérés à partir de différents courants horizontaux de féminismes - noir, universitaire, lésbien, masculin, etc.

MOTS-CLES: théorie et mouvement féministe; justice; participation politique; transversalité; intersectionalité de sexes. 